Khalid Abdoun, Friederike Stumpff, Imtiaz Rabbani and Holger Martens

Am J Physiol Gastrointest Liver Physiol 298:190-202, 2010. First published Nov 19, 2009;

doi:10.1152/ajpgi.00216.2009

You might find this additional information useful...

This article cites 87 articles, 42 of which you can access free at:

http://ajpgi.physiology.org/cgi/content/full/298/2/G190\#BIBL

Updated information and services including high-resolution figures, can be found at:

http://ajpgi.physiology.org/cgi/content/full/298/2/G190

Additional material and information about AJP - Gastrointestinal and Liver Physiology can be found at: http://www.the-aps.org/publications/ajpgi

This information is current as of August 25, 2010 .

AJP - Gastrointestinal and Liver Physiology publishes original articles pertaining to all aspects of research involving normal or abnormal function of the gastrointestinal tract, hepatobiliary system, and pancreas. It is published 12 times a year (monthly) by the American Physiological Society, 9650 Rockville Pike, Bethesda MD 20814-3991. Copyright @ 2010 by the American Physiological Society. ISSN: 0193-1857, ESSN: 1522-1547. Visit our website at http://www.the-aps.org/. 


\title{
Modulation of urea transport across sheep rumen epithelium in vitro by SCFA
} and $\mathrm{CO}_{2}$

\author{
Khalid Abdoun, ${ }^{1,2 *}$ Friederike Stumpff, ${ }^{1 *}$ Imtiaz Rabbani, ${ }^{1,3}$ and Holger Martens ${ }^{1}$ \\ ${ }^{1}$ Institute of Veterinary Physiology, Free University of Berlin, Berlin, Germany; ${ }^{2}$ Department of Physiology, Faculty \\ of Veterinary Sciences, University of Khartoum, Sudan; and ${ }^{3}$ University of Veterinary and Animal Sciences, Lahore, Pakistan
}

Submitted 10 June 2009; accepted in final form 9 November 2009

\begin{abstract}
Abdoun K, Stumpff F, Rabbani I, Martens H. Modulation of urea transport across sheep rumen epithelium in vitro by SCFA and $\mathrm{CO}_{2}$. Am J Physiol Gastrointest Liver Physiol 298: G190-G202, 2010. First published November 19, 2009; doi:10.1152/ajpgi.00216.2009.-Urea transport across the gastrointestinal tract involves transporters of the urea transporter-B group, the regulation of which is poorly understood. The classical stimulatory effect of $\mathrm{CO}_{2}$ and the effect of short-chain fatty acids (SCFA) on the ruminal recycling of urea were investigated by using Ussing chamber and microelectrode techniques with isolated ruminal epithelium of sheep. The flux of urea was found to be phloretin sensitive and passive. At a luminal $\mathrm{pH}$ of 6.4, but not at 7.4, the addition of SCFA (40 mmol/l) or $\mathrm{CO}_{2} / \mathrm{HCO}_{3}^{-}(10 \%$ and 25 $\mathrm{mmol} / \mathrm{l})$ led to a fourfold increase in urea flux. The stepwise reduction of luminal $\mathrm{pH}$ in the presence of SCFA from 7.4 to 5.4 led to a bell-shaped modification of urea transport, with a maximum at $\mathrm{pH} 6.2$. Lowering the $\mathrm{pH}$ in the absence of SCFA or $\mathrm{CO}_{2}$ had no effect. Inhibition of $\mathrm{Na}^{+} / \mathrm{H}^{+}$exchange increased urea flux at $\mathrm{pH} 7.4$, with a decrease being seen at $\mathrm{pH}$ 6.4. In experiments with double-barreled, $\mathrm{pH}$-sensitive microelectrodes, we confirmed the presence of an apical $\mathrm{pH}$ microclimate and demonstrated the acidifying effects of SCFA on the underlying epithelium. We confirm that the permeability of the ruminal epithelium to urea involves a phloretin-sensitive pathway. We present clear evidence for the regulation of urea transport by strategies that alter intracellular $\mathrm{pH}$, with permeability being highest after a moderate decrease. The well-known postprandial stimulation of urea transport to the rumen in vivo may involve acute $\mathrm{pH}$-dependent effects of intraruminal SCFA and $\mathrm{CO}_{2}$ on the function of existing urea transporters.
\end{abstract}

$\mathrm{pH}_{\mathrm{i}}$; urea transporter- $\mathrm{B}$; short-chain fatty acids; microclimate; volatile fatty acid

UREA, POSSIBLY BECAUSE OF its small size, was long thought to move passively across epithelia, depending only on the rate of delivery via blood. The urea permeability of cellular membranes has now been established to be several orders of magnitude above that of lipid membranes $(11,92)$ and is coupled to the expression of specific urea-transporting proteins with channel-like kinetics $(7,46,71,81,82,95)$. Whereas the role that these proteins play in the elegant renal concentrating mechanism has received much attention, their function and regulation in other parts of the body, such as the gut (39), continues to be poorly understood.

In contrast to the paucity of our knowledge concerning extrarenal urea transport in humans, we have long known of the ability of camels, cows, or sheep to shift the excretion of urea from the kidney $(62,72)$ to the gastrointestinal tract (79). The transport of urea through the rumen epithelium was first

\footnotetext{
* K. Abdoun and F. Stumpff contributed equally to this work.

Address for reprint requests and other correspondence: H. Martens, Dept. of Veterinary Physiology, Free Univ. of Berlin, Oertzenweg 19b, 14163 Berlin, Germany (e-mail: martens@vetmed.fu-berlin.de).
}

demonstrated many years ago in vivo and in vitro $(16,29,79$, 89 ) and the physiological significance is clear: in the rumen, dietary cellulose is broken down by bacteria that utilize ureanitrogen for the synthesis of microbial proteins. After passage into the duodenum, the amino acids of these proteins are absorbed and reach the liver, where new urea for secretion into the rumen can be formed. Recycling of nitrogen via urea secretion into the rumen thus allows these animals to survive on low-protein diets while producing milk and meat for human consumption $(1,41,67)$. The quantities of nitrogen recycled vary widely and might account for up to $25 \%$ of the nitrogen ingested (60) or up to $90 \%$ of urea turnover (for reviews, see Refs. 35, 44, 50, 67).

Our understanding of the mechanisms by which urea is transported across the rumen epithelium has evolved gradually. Gärtner and coworkers $(16,28,29)$ originally postulated a saturable carrier for urea on the basis of observations of an inverse correlation between renal and ruminal urea excretion rates with no clear correlation to plasma urea levels. These studies were later challenged $(38,89)$, and, for a number of years, an uneasy consensus supporting ruminal urea transport via lipid diffusion reemerged. However, this hypothesis could not explain the outcome of feeding studies $(13,34,36,41,59$, 60 ), leading to the suggestion that the recycling of urea into the rumen is not determined by plasma urea levels but involves changes in the permeability of the rumen epithelium in response to dietary stimuli (35).

Current models of ruminal urea transport suggest that, whereas the concentration gradient serves as a driving force for the entry of urea from the blood into the rumen, the rate of influx is regulated in a far more complex manner $(1,35,41,44$, $67,90)$, involving both long-term adaptation and a system of short-term regulation corresponding to a postprandial increase in the extraction rate of arterial urea by the rumen $(44,50,64$, $65)$. Thus, when feed is supplemented with a rapidly fermentable energy source, the daily flux of urea across the rumen wall increases up to twofold $(41,58-60,86)$ and, in the 3-h interval after a meal, urea flux into the rumen can rise even further (64). This mechanism allows the animal to capitalize on available carbohydrates by an endogenous supply of nitrogen (33). As the blood urea level decreases when these energy supplements are added, the increase in urea flux must be mainly attributable to modified rumen epithelial permeability via changes in the expression level or permeability of urea-transporting membrane proteins.

Cytohistochemical studies have led to the model of a functional syncytium of the multilayered rumen epithelium with an epithelial permeability barrier (with zonae occludentes) at the level of the stratum granulosum. The cell layers are interconnected by gap junctions from the stratum granulosum via the 
stratum spinosum to the stratum basale, where expression of $\mathrm{Na}^{+}-\mathrm{K}^{+}$-ATPase is concentrated (32). Recent studies have shown that urea transporter mRNA and protein corresponding to urea transporter-B (UT-B; splice variants 1 and 2) $(51,52)$ are present in the epithelium of the rumen and colon of sheep $(68,69)$. In addition, staining for UT-B has been demonstrated in the membranes of all epithelial layers of the bovine rumen with the exception of the stratum corneum $(80,83)$.

Intriguingly, a recent study has shown the stimulatory effects of a 2-wk diet with induction of low ruminal $\mathrm{pH}$ and an elevation of intraruminal butyrate on the localization and expression of UT-B in the rumen (80). The future will show whether long-term effects of butyrate on urea transport are indeed related to a higher density of urea transporters in the ruminal tissue or whether concomitant increases in ruminal surface area are sufficient to explain these effects $(24,90)$. In general, however, the demonstration of an effect of dietary changes on the expression of gastrointestinal urea transporters in ruminants has been challenging $(18,48,51,61,80)$.

Whatever the ultimate reasons for long-term changes in urea transport, changes in surface area cannot explain the rapid short-term diurnal variations in urea transport in response to fermentational processes with the release of $\mathrm{CO}_{2}$ and SCFA. Thus the bubbling of $\mathrm{CO}_{2}$ into the rumen $(65,87,90)$ leads to a rapid rise in urea transfer to the rumen, with effects seen after as little as $15 \mathrm{~min}$ (65). Increases in blood flow have been discussed but cannot explain the magnitude of the effect (19, 66). Conversely, the effects of SCFA on urea transport are less clear. Whereas acute stimulatory effects of butyrate were observed in two studies of urea transport into the rumen in toto (87) and into an isolated ruminal pouch (90), an inverse effect was observed in a later study (65). Difficulties in controlling various parameters in vivo with an impact on urea transport (such as ammonia) may explain these discrepancies $(65,87,90)$.

The aim of the present study has therefore been directly to examine the effect of SCFA and $\mathrm{CO}_{2}$ on urea fluxes across the freshly isolated rumen epithelium of sheep in the controlled environment of the Ussing chamber. Depending on mucosal $\mathrm{pH}$, we were able to observe a fourfold stimulation of ruminal urea transport by SCFA and $\mathrm{CO}_{2}$ under in vitro conditions. The effects of SCFA are maximal in the $\mathrm{pH}$ range from $\sim 6.2$ to 6.4 (found physiologically in the rumen) and decrease with alkaline or acidic deviation from this value. In experiments with $\mathrm{pH}$-sensitive microelectrodes, we were able to demonstrate that, at a $\mathrm{pH}$ of 6.4 , the addition of SCFA has a significant acidifying effect on the cytosolic space of the transporting layer of cells. We suggest that the rapid increase in urea transport that is observed postprandially in vivo occurs in response to SCFA and $\mathrm{CO}_{2}$ and is functional rather than transcriptional, involving acute effects of $\mathrm{pH}$ on the activity of a urea-transporting protein that is likely to be UT-B $(51,52,68$, $69,80,83)$.

\section{MATERIALS AND METHODS}

\section{Flux Measurements in the Ussing Chamber}

Isolation and incubation of rumen epithelium. The incubation of rumen epithelium has been described in detail by Abdoun et al. (2). Briefly, sheep were killed in a local slaughterhouse, and the reticulorumen was removed from the abdominal cavity within $2-3 \mathrm{~min}$. A $250-\mathrm{cm}^{2}$ piece of rumen wall was taken from the ventral sac, cleaned in a buffer solution, stripped from the muscle layer, taken (duration: $\sim 20 \mathrm{~min}$ ) to the laboratory in a physiological buffer solution, and maintained at $38^{\circ} \mathrm{C}$. The buffer was gassed with $95 \% \mathrm{O}_{2}-5 \% \mathrm{CO}_{2}$ during transportation. Pieces of the epithelium $(3 \times 3 \mathrm{~cm})$ were mounted between the two halves of an Ussing chamber to give an exposed area of $3.14 \mathrm{~cm}^{2}$. The mounted tissues were bathed on each side with $16 \mathrm{ml}$ of buffer solution by using a gas-lift system and were gassed with $95 \% \mathrm{O}_{2}-5 \% \mathrm{CO}_{2}, 90 \% \mathrm{O}_{2}-10 \% \mathrm{CO}_{2}$, or $100 \% \mathrm{O}_{2}$ ( $\mathrm{HCO}_{3}^{-}$-free buffer solutions) at $38^{\circ} \mathrm{C}$.

The standard electrolyte solution contained (in mmol/l) $140 \mathrm{Na}^{+}, 5$ $\mathrm{K}^{+}, 1 \mathrm{Ca}^{2+}, 1 \mathrm{Mg}^{2+}, 104 \mathrm{Cl}^{-}, 1 \mathrm{H}_{2} \mathrm{PO}_{4}^{-}, 2 \mathrm{HPO}_{4}^{2-}, 10$ glucose, and 40 gluconate, with 1 phenyl-phosphorodiamidate (urease inhibitor) and urea added at $1 \mathrm{mmol} / \mathrm{l}$ or as indicated. $\mathrm{In} \mathrm{HCO}_{3}^{-}$-containing solutions, $25 \mathrm{mmol} / \mathrm{l}$ gluconate was replaced by $25 \mathrm{mmol} / 1 \mathrm{HCO}_{3}^{-}$. In SCFA-containing solutions, $40 \mathrm{mmol} / \mathrm{l}$ gluconate was replaced by 25 $\mathrm{mmol} / \mathrm{l}$ acetate, $10 \mathrm{mmol} / \mathrm{l}$ propionate, and $5 \mathrm{mmol} / \mathrm{l}$ butyrate. These concentrations are well tolerated by the tissue in vitro and reflect the relative proportions found in the rumen physiologically.

In solutions containing both $\mathrm{HCO}_{3}^{-}$and SCFA, the concentration of chloride was lowered by $25 \mathrm{mmol} / \mathrm{l}$. Mannitol was used to adjust the osmolarity of all solutions to $305 \mathrm{mosmol} / \mathrm{l}$ (Osmomat 030-D, GONOTEC, Berlin). In experiments in which mannitol fluxes were measured, 1, 3, 5 , and $7 \mathrm{mmol} / \mathrm{l}$ mannitol were added to the corresponding buffers without renewed adjustment for osmolarity, which thus differed by small amounts $(<7 \mathrm{mmol} / \mathrm{l})$.

Bicarbonate-free solutions were buffered with $8 \mathrm{mmol} / \mathrm{l}$ MOPS $\left(\mathrm{C}_{7} \mathrm{H}_{15} \mathrm{NO}_{4} \mathrm{~S}\right)$. All solutions were adjusted to a standard $\mathrm{pH}$ of 7.4 or as indicated by using Tris $\left[\left(\mathrm{HOCH}_{2}\right)_{3} \mathrm{CNH}_{2}\right]$ or MES $\left(\mathrm{C}_{6} \mathrm{H}_{13} \mathrm{NO}_{4} \mathrm{~S}\right)$ buffers, and antibiotics were added [penicillin G, kanamycin, and 5-fluorocytosine (55)]. Antibiotics, amiloride, and phloretin were obtained from Sigma (Munich, Germany). Phenyl phosphorodiamidate was obtained from ABCR (Karlsruhe, Germany). Radioisotope ${ }^{14} \mathrm{C}$-urea was purchased from Hartmann Analytik (Braunschweig, Germany), ${ }^{36} \mathrm{Cl}$ was from Amersham (Braunschweig, Germany), and ${ }^{3} \mathrm{H}$-labeled mannitol was purchased from Perkin Elmer, Germany (Rodgau-Jügesheim). All reagents were of analytical grade.

Electrical measurements and measurement of flux rates. The transepithelial conductance $\left(\mathrm{G}_{\mathrm{t}}\right)$ was determined by applying a $100-\mu \mathrm{A}$ current for $1 \mathrm{~s}$ across the tissue in both directions and measuring the resulting change in transmural potential difference $\left(\mathrm{PD}_{\mathrm{t}}\right)$, from which $\mathrm{G}_{\mathrm{t}}$ can be calculated by using Ohm's law (Mussler Scientific Instruments, Aachen/Germany). The sum of all electrogenic ions moving across the tissue was determined by measuring the external current

Table 1. Effect of SCFA on unidirectional urea flux rates across the rumen epithelium under control conditions (pH 7.4) in absence of $\mathrm{CO}_{2} / \mathrm{HCO}_{3}^{-}$

\begin{tabular}{|c|c|c|c|c|c|c|}
\hline Group & $J_{\mathrm{ms}}^{\mathrm{urea}}, \mathrm{nmol} \cdot \mathrm{cm}^{-2} \cdot \mathrm{h}^{-1}$ & $J_{\mathrm{sm}}^{\mathrm{urea}}, \mathrm{nmol} \cdot \mathrm{cm}^{-2} \cdot \mathrm{h}^{-1}$ & $J_{\text {net }}^{\text {urea }}, \mathrm{nmol} \cdot \mathrm{cm}^{-2} \cdot \mathrm{h}^{-1}$ & $I_{\mathrm{sc}}, \mu \mathrm{eq} \cdot \mathrm{cm}^{-2} \cdot \mathrm{h}^{-1}$ & $\mathrm{G}_{\mathrm{t}}, \mathrm{mS} \cdot \mathrm{cm}^{-2}$ & $N / n$ \\
\hline $\mathrm{pH} 7.4-\mathrm{SCFA}$ & $20.8 \pm 1.8$ & $21.8 \pm 2.1$ & $+1.0 \pm 1.4$ & $0.7 \pm 0.1 *$ & $2.7 \pm 0.1$ & $3 / 9$ \\
\hline pH 7.4+SCFA & $22.8 \pm 2.4$ & $22.6 \pm 2.4$ & $+0.1 \pm 2.5$ & $1.0 \pm 0.1 \dagger$ & $2.8 \pm 0.1$ & $3 / 9$ \\
\hline
\end{tabular}

Values are means \pm SE. SCFA, short-chain fatty acids; $J_{\mathrm{ms}}^{\text {urea }}$, mucosal-to-serosal urea flux rate; $J_{\mathrm{sm}}^{\text {urea }}$, serosal-to-mucosal urea flux rate; $J_{\text {net }}^{\text {urea }}$, net urea transport; $I_{\mathrm{sc}}$, short-circuit current; $\mathrm{G}_{\mathrm{t}}$, transepithelial conductance. $N=$ number of animals; $n=$ number of tissues for each treatment. Values in the same column bearing different symbols are significantly different at $P<0.05$ (paired $t$-test). 
Table 2. Effect of $\mathrm{CO}_{2} / \mathrm{HCO}_{3}^{-}$on unidirectional urea flux rates across the rumen epithelium under control conditions (pH 7.4)

\begin{tabular}{lccccc}
\hline \hline Group & $J_{\text {ms }}^{\text {urea }}, \mathrm{nmol} \cdot \mathrm{cm}^{-2} \cdot \mathrm{h}^{-1}$ & $J_{\mathrm{sm}}^{\text {urea }}, \mathrm{nmol} \cdot \mathrm{cm}^{-2} \cdot \mathrm{h}^{-1}$ & $J_{\text {net }}^{\text {urea }}, \mathrm{nmol} \cdot \mathrm{cm}^{-2} \cdot \mathrm{h}^{-1}$ & $I_{\mathrm{sc}}, \mu \mathrm{eq} \cdot \mathrm{cm}^{-2} \cdot \mathrm{h}^{-1}$ & $\mathrm{G}_{\mathrm{t}}, \mathrm{mS} \cdot \mathrm{cm}^{-2}$ \\
\hline Control & $20.7 \pm 4.9^{*}$ & $23.1 \pm 6.9^{*}$ & $-3.1 \pm 9.6$ & $0.6 \pm 0.1 *$ & $2.5 \pm 0.1$ \\
$\mathrm{CO}_{2}$ & $31.5 \pm 6.5 \dagger$ & $31.1 \pm 9.3 \dagger$ & $0.4 \pm 15.1$ & $1.2 \pm 0.1 \dagger$ & $3.5 \pm 0.2$ \\
\hline
\end{tabular}

Values are means \pm SE. Absence of SCFA; $N=$ number of animals; $n=$ number of tissues for each treatment. Values in the same column bearing different symbols are significantly different at $P<0.05$ (unpaired $t$-test).

[equivalent to short-circuit current $\left(I_{\mathrm{sc}}\right)$ ] necessary for clamping $\mathrm{PD}_{\mathrm{t}}$ to zero.

${ }^{14}$ C-labeled urea (46.25 kBq) was added to the "hot" side of the epithelium, and three flux periods of 20 min were performed after an equilibration time of $40 \mathrm{~min}$. Samples from the hot side were taken before the first and after the last flux period for the calculation of the specific radioactivity and assayed by using a $\beta$-counter (LKB Wallace-Perkin-Elmer; überlingen, Germany). The sample volume was replaced by the corresponding buffer.

Chloride and mannitol fluxes were measured essentially as described previously $(2,73,74)$. All measurements were performed under classical Ussing chamber conditions without chemical gradients and with transepithelial potential clamped to $0 \mathrm{mV}$ in the short-circuit mode. In accordance with these requirements and in correspondence to previous studies with SCFA $(26,77)$, SCFA were added to both sides of the tissue.

\section{Patch-Clamp Measurements}

Patch-clamp measurements were performed as reported previously $(84,85)$. In brief, ruminal epithelial cells were isolated by fractional trypsinization and cultured on coverslips. Extracellular $\mathrm{NaCl}$ solution contained (in mmol/l) $115 \mathrm{NaCl}, 1 \mathrm{NaH}_{2} \mathrm{PO}_{4}, 5 \mathrm{KCl}, 10$ HEPES, 1.7 $\mathrm{CaCl}_{2}$, and $0.9 \mathrm{MgCl}_{2}$, to which $30 \mathrm{mmol} / 1$ urea or mannitol was added as indicated. Cells were filled with a solution that contained (in mmol/l) $123 \mathrm{~K}$-gluconate, $10 \mathrm{NaCl}, 1 \mathrm{KH}_{2} \mathrm{PO}_{4}, 10 \mathrm{HEPES}, 0.8 \mathrm{CaCl}_{2}$, $0.9 \mathrm{MgCl}_{2}$, and 5 EGTA. From a holding potential of $-40 \mathrm{mV}$, the voltage was stepped from -120 to $100 \mathrm{mV}$, with a step size of $10 \mathrm{mV}$, and currents were measured with an EPC 9 patch-clamp amplifier (HEKA Elektronic, Lambrecht, Germany).

\section{Microelectrode Experiments}

Electrical measurements. Fresh ruminal epithelium was introduced into a small microelectrode chamber, apical side up. The apical and

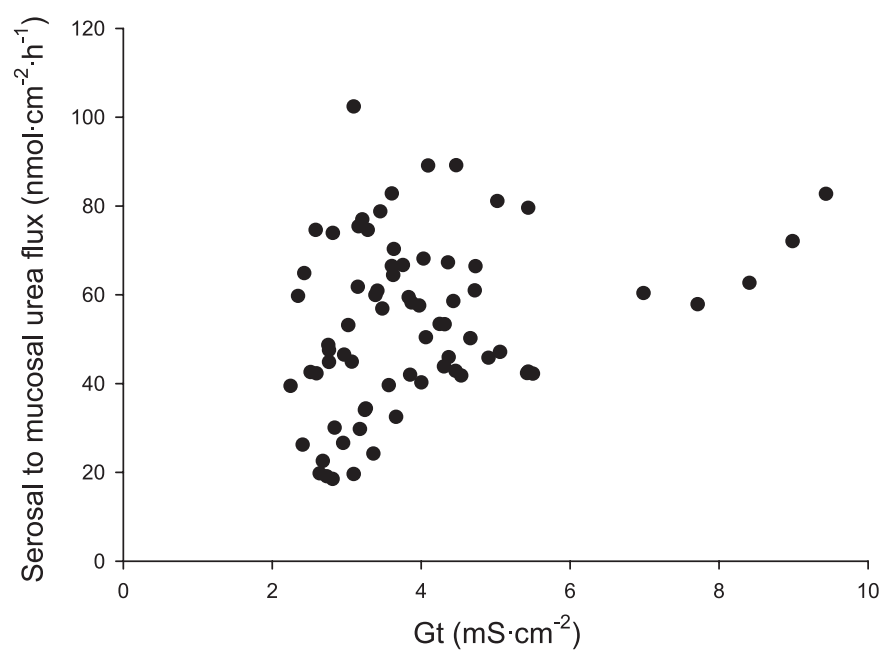

Fig. 1. Plot of the serosal-to-mucosal urea flux rates across the rumen epithelium against transepithelial conductance $\left(G_{t}\right)$ in the presence of shortchain fatty acid (SCFA; $n=73$ ). There is no significant correlation. basolateral sides of the chamber were continuously perfused (MS/ CA4/840, Ismatec, Glattbrugg-Zürich, Switzerland) with solution warmed to $37^{\circ} \mathrm{C}$ essentially as previously described $(84,85)$. The composition of the solutions was the same as in the bicarbonate-free solutions used in the Ussing chamber experiments, with MOPS being used to buffer $\mathrm{pH}$ and gluconate being replaced by SCFA as indicated. Solutions were bubbled with $\mathrm{O}_{2}$ throughout. The $\mathrm{pH}$ of the experimental solutions was monitored at hourly intervals by using a conventional $\mathrm{pH}$ meter (Inolab $\mathrm{pH} 720$, Weilheim, Germany) and adjusted if necessary.

The transepithelial voltage, resistance, and $I_{\mathrm{sc}}$ of the tissues were controlled via voltage clamp (Biomedical Instruments, Munich, Germany) (43). The potentials of the two barrels of the microelectrode were measured with an FDA223 Dual Electrometer (World Precision Instruments, Sarasota, FL) and referenced to the mucosal side of the bath via a $\mathrm{KCl}$ bridge. All parameters were recorded by using Chart 5 for Windows (ADInstruments, Bella Vista, NSW, Australia) and filtered with digital median filters. The fractional apical resistance $f\left(\mathrm{R}_{\mathrm{a}}\right)$ was calculated from the potential response $\left(\Delta \mathrm{V}_{\mathrm{a}}\right)$ of the microelectrode to $10 \mathrm{mV}$ transepithelial voltage pulses of $0.3 \mathrm{~s}$ duration $\left(\Delta \mathrm{V}_{\mathrm{t}}\right)(23)$, i.e., $\left[f\left(\mathrm{R}_{\mathrm{a}}\right)(\%)=\Delta \mathrm{V}_{\mathrm{a}} / \Delta \mathrm{V}_{\mathrm{t}} \times 100\right]$ (Fig. 7).

Manufacture of double-barrelled pH-sensitive microelectrodes. Piggy-back double-barreled microelectrodes were prepared from filamented GC120F 10 and GC150F 15 borosilicate glass tubing (Harvard Apparatus, Kent, UK). One end of the smaller diameter tubing (GC120F 10) was heated and gently bent at a small angle from the main shaft (17). Two core cable ends $(4 \times 10,611889$, Conrad Bauelemente, Conrad Elektronik, Hirschau, Germany) were pushed into tightly fitting shrink tubing (Deray-H-set $1 / 8^{\prime \prime}$, DSG-Canusa, Meckenheim, Germany) and used to join this bent glass tube with the larger diameter tube, leaving the middle section free of tubing. After being baked $\left(190^{\circ} \mathrm{C}\right)$ until firmly adjoined, the piggyback electrodes were pulled by using a programmable multipipette puller (PMP-107, Microdata Instrument, South Plainfield, NJ) to give a resistance of

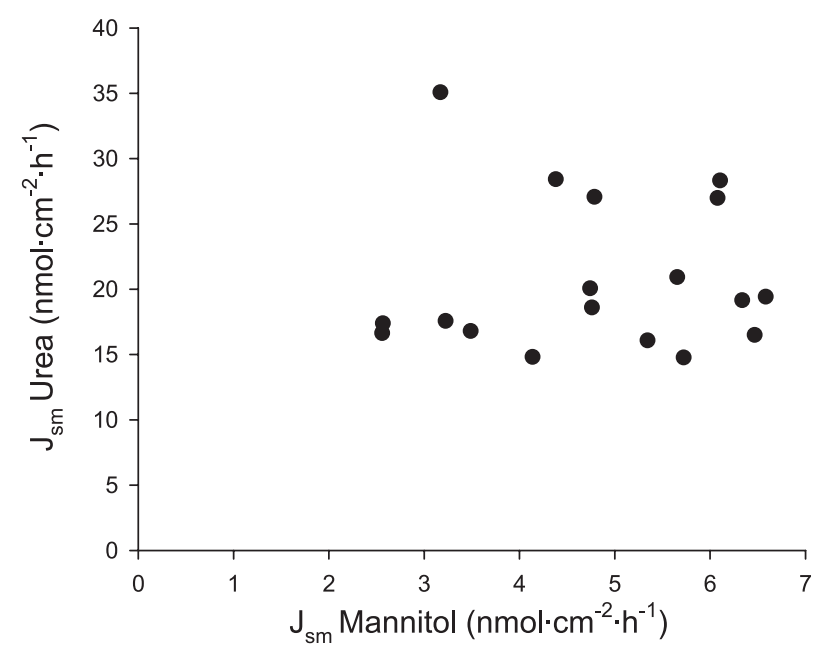

Fig. 2. Serosal-to-mucosal $\left(J_{\mathrm{sm}}\right)$ transport rates of mannitol and urea across the isolated rumen epithelium of sheep at $\mathrm{pH} 7.4$ in the presence of SCFA $(N=$ $3, n=18$ ), showing no correlation. 


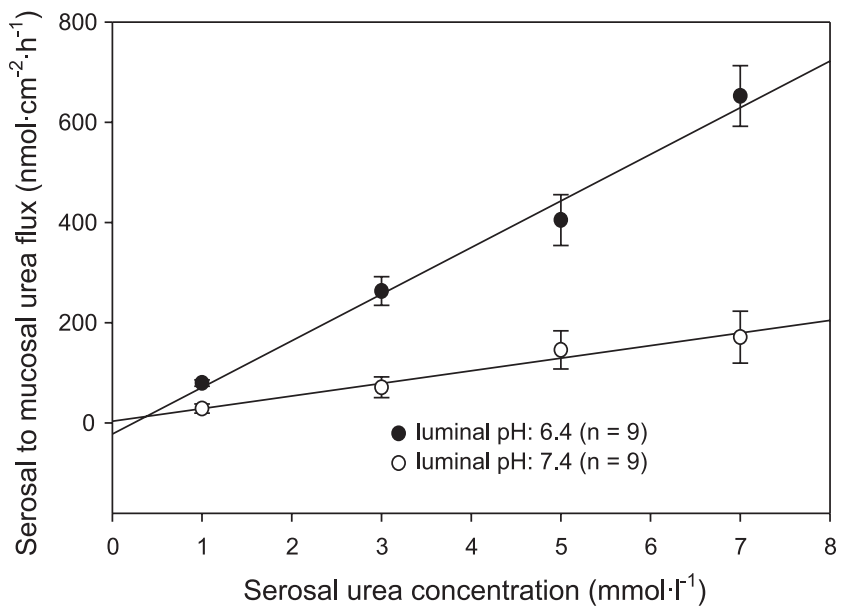

Fig. 3. Serosal concentrations of urea and $J_{\mathrm{sm}}$ urea across the rumen epithelium at a luminal $\mathrm{pH}$ of 7.4 and 6.4 in the presence of SCFA. Each point corresponds to the mean value of flux data from 9 epithelia from 3 different animals $(N=3 ; n=9)$. The data in the $2 \mathrm{pH}$ groups were significantly different $(P<0.05$, paired $t$-test $)$ and correlated linearly with serosal urea concentration according to

$J_{\mathrm{sm}}(7.4)=25.1 \cdot 10^{-6} \cdot[$ urea $] \cdot 1 \cdot \mathrm{cm}^{-2} \cdot \mathrm{h}^{-1}+3.7 \mathrm{nmol} \cdot \mathrm{cm}^{-2} \cdot \mathrm{h}^{-1}\left(r^{2}=0.98\right)$

and

$$
J_{\mathrm{sm}}(6.4)=93 \cdot 10^{-6} \cdot[\text { urea }] \cdot 1 \cdot \mathrm{cm}^{-2} \cdot \mathrm{h}^{-1}-22 \mathrm{nmol} \cdot \mathrm{cm}^{-2} \cdot \mathrm{h}^{-1}\left(r^{2}=0.99\right) .
$$

[urea], Urea concentration.

$\sim 50 \mathrm{M} \Omega$ (measured with EPC 9, Heka Elektronik, Lambrecht, Germany).

For silanization, the bent ends were connected to a pressure source and perfused with dried air, while the straight ends were pushed into the rubber lid of a heated glass jar and exposed to the vapor formed by a drop $(200 \mu \mathrm{l})$ of dichlorodimethylsilane (Sigma-Aldrich) for 30 min. Pipettes were then baked at $190^{\circ} \mathrm{C}$ for $2 \mathrm{~h}$, after which time the silanized channel was immediately backfilled with $3 \mu$ l Hydrogen Ionophore I-Cocktail A (Sigma Aldrich) via a modified Hamilton syringe (type $7000.50 \mathrm{C}, 0.5 \mathrm{ml}$, MedChrom, Germany). In some experiments, Theta glass tubing (TGC150-7.5, Harvard Apparatus) was used but, in this case, it proved more difficult to silanize one channel selectively.

The filled pipettes were placed tip downward in a jar containing a dehydrating agent at least overnight to allow the hydrogen ionophore to diffuse into the tip of the electrode. On the day before use, the hydrogen-sensitive barrel was backfilled with a solution containing $100 \mathrm{mmol} / \mathrm{l} \mathrm{KCl}, 20 \mathrm{mmol} / \mathrm{l} \mathrm{HEPES}, \mathrm{pH}$ 7.4. The reference channel was filled with $0.5 \mathrm{mmol} / \mathrm{l} \mathrm{KCl}$. Both solutions were degassed by heating at $40^{\circ} \mathrm{C}$ before use.

To achieve functional microelectrodes, residual clogging silane had to be removed. Controlled breakage $(17,88)$ yielded unsatisfactory results. Use of a micromanipulator to push the electrode through a piece of tissue paper (Kimwipe Lite 200, Kimberly-Clark) clamped

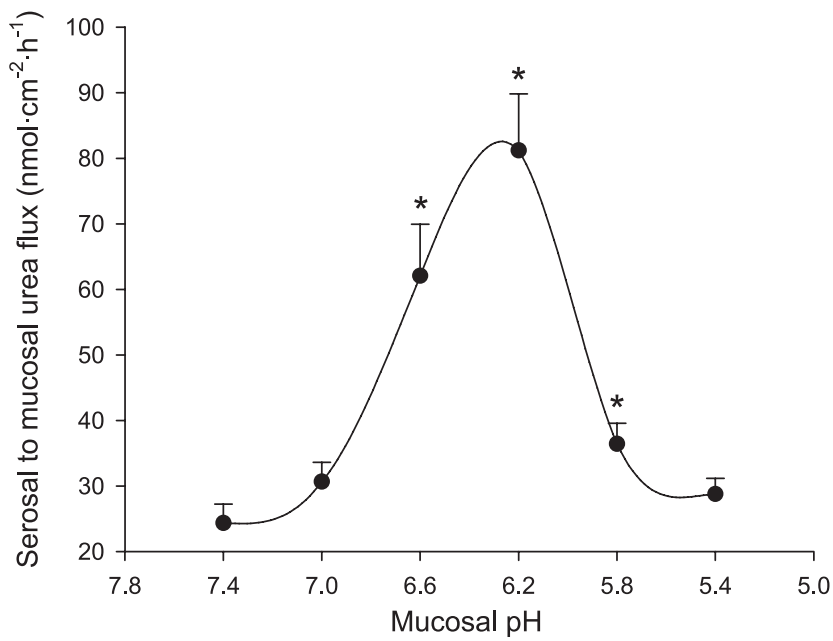

Fig. 4. Effect of decreasing mucosal $\mathrm{pH}$ on $J_{\mathrm{sm}}$ urea flux across the rumen epithelium in the presence of SCFA [absence of $\mathrm{CO}_{2} / \mathrm{HCO}_{3}^{-}, N=2 ; n=8$, $* P<0.5$ vs. pH 7.4 (paired $t$-test)].

into the microelectrode chamber under a microscope yielded better resistances of 5-10 M $\Omega$. In the final stages of the study, a beveller with an impedance meter was purchased (BV-10, Sutter Instrument, Novato, CA) for this purpose; the routine manufacture of functional microelectrodes with resistances $>20 \mathrm{M} \Omega$ was thereby greatly facilitated.

Electrodes were judged suitable for impalement if they showed a differential response of over $40 \mathrm{mV}$ per $\mathrm{pH}$ unit $(\mathrm{mV} / \mathrm{pH})(\mathrm{pH} 7.4$ to $\mathrm{pH}$ 6.4) between the $\mathrm{pH}$-selective and nonselective barrel immediately before the experiments commenced. This test pulse was used to calculate cytosolic $\mathrm{pH}$ via linear regression. The speed of $\mathrm{pH}$ change was calculated for each point by subtracting the $\mathrm{pH}$ level from the value measured $30 \mathrm{~s}$ previously by using Chart for Windows.

Care was taken to choose the sharpest electrodes from the 16 typically available on a given experimental day. Impalements were judged to be stable if the fractional apical resistance remained constant. The resistances of functional microelectrodes were checked after successful completion of the experiment and typically yielded values of over 2 but under $10 \mathrm{M} \Omega$. These resistances are thus clearly lower than desirable, which may explain why the apical potentials measured with $\mathrm{pH}$-sensitive microelectrodes tended to be less negative and less stable than those measured previously with singlebarrelled electrodes (43).

Measurements. All tissues were allowed to settle in $\mathrm{HCO}_{3}^{-}$-free solution at $\mathrm{pH} 7.4$ for 10 min before experiments commenced. Tissues were kept in the open-circuit mode but briefly clamped from time to time to measure the $I_{\mathrm{sc}}\left(0.63 \pm 0.11 \mu \mathrm{eq} \cdot \mathrm{cm}^{-2} \cdot \mathrm{h}^{-1}\right)$ and tissue conductance $\left(3.1 \pm 0.5 \mathrm{mS} / \mathrm{cm}^{2}\right)$. All microelectrodes were rechecked for function by briefly changing the apical perfusion solution to an identical solution buffered to $\mathrm{pH} 6.4$ (Fig. 7) before the start of the actual experiment, yielding an average sensitivity of $53 \pm 4 \mathrm{mV} / \mathrm{pH}$

Table 3. Effect of short chain fatty acids and $\mathrm{Na}^{+} / \mathrm{H}^{+}$-exchanger activity on bidirectional urea flux rates across the rumen epithelium in absence of $\mathrm{CO}_{2} / \mathrm{HCO}_{3}^{-}$

\begin{tabular}{|c|c|c|c|c|c|c|}
\hline Group & $J_{\mathrm{ms}}^{\text {urea }}, \mathrm{nmol} \cdot \mathrm{cm}^{-2} \cdot \mathrm{h}^{-1}$ & $J_{\mathrm{sm}}^{\text {urea }}, \mathrm{nmol} \cdot \mathrm{cm}^{-2} \cdot \mathrm{h}^{-1}$ & $J_{\text {net }}^{\text {urea }}, \mathrm{nmol} \cdot \mathrm{cm}^{-2} \cdot \mathrm{h}^{-1}$ & $I_{\mathrm{sc}}, \mu \mathrm{eq} \cdot \mathrm{cm}^{-2} \cdot \mathrm{h}^{-1}$ & $\mathrm{G}_{\mathrm{t}}, \mathrm{mS} \cdot \mathrm{cm}^{-2}$ & $N / n$ \\
\hline pH 6.4-SCFA & $21.0 \pm 2.1^{*}$ & $22.8 \pm 2.3^{*}$ & $-1.7 \pm 1.3^{*}$ & $0.7 \pm 0.1^{*}$ & $2.7 \pm 0.1^{*}$ & $3 / 9$ \\
\hline pH $6.4+$ SCFA & $83.6 \pm 16.4 \dagger$ & $82.4 \pm 12.1 \dagger$ & $1.2 \pm 10.3^{*}$ & $0.6 \pm 0.1^{*}$ & $2.3 \pm 0.1^{*}$ & $3 / 9$ \\
\hline
\end{tabular}

Values are means \pm SE. $N=$ number of animals; $n=$ number of tissues for each treatment. Values in the same column bearing different symbols are significantly different at $P<0.05$ (Dunnett's $t$-test). 
Table 4. Effects of $\mathrm{CO}_{2}$ and mucosal pH on bidirectional urea flux rates across the rumen epithelium in absence of SCFA

\begin{tabular}{|c|c|c|c|c|c|c|}
\hline Group & $J_{\mathrm{ms}}^{\text {urea }}, \mathrm{nmol} \cdot \mathrm{cm}^{-2} \cdot \mathrm{h}^{-1}$ & $J_{\mathrm{sm}}^{\text {urea }}, \mathrm{nmol} \cdot \mathrm{cm}^{-2} \cdot \mathrm{h}^{-1}$ & $J_{\text {net }}^{\text {urea }}, \mathrm{nmol} \cdot \mathrm{cm}^{-2} \cdot \mathrm{h}^{-1}$ & $I_{\mathrm{sc}}, \mu \mathrm{eq} \cdot \mathrm{cm}^{-2} \cdot \mathrm{h}^{-1}$ & $\mathrm{G}_{\mathrm{t}}, \mathrm{mS} \cdot \mathrm{cm}^{-2}$ & $N / n$ \\
\hline $\mathrm{pH} 6.4,5 \% \mathrm{CO}_{2}$ & $68.1 \pm 2.0 \dagger$ & $63.9 \pm 2.3 \dagger$ & $4.1 \pm 1.3$ & $1.5 \pm 0.1^{*}$ & $2.9 \pm 0.2$ & $3 / 9$ \\
\hline $\mathrm{pH} 7.4,10 \% \mathrm{CO}_{2}$ & $43.6 \pm 16.4 \ddagger$ & $39.2 \pm 12.0 \ddagger$ & $4.4 \pm 10.3$ & $1.5 \pm 0.5^{*}$ & $3.3 \pm 0.2$ & $3 / 9$ \\
\hline
\end{tabular}

Values are means \pm SE. $N=$ number of animals; $n=$ number of tissues for each treatment. Values in the same column bearing different symbols are significantly different at $P<0.05$ (Dunnett's $t$-test).

unit. The $\mathrm{pH}$ response of the pipettes to the change in external solution was rapid, reaching a maximal speed of $1.93 \pm 0.05 \mathrm{pH} / \mathrm{min}$.

\section{Statistics}

To allow a paired comparison of tissues from the same animal exposed to different treatments, a total of 24 Ussing chambers were available for experiments on each experimental day. All evaluations were carried out by using Sigma Stat (3.0.1) and Sigma Plot program version 8.0 for Windows (SPSS, Chicago, IL). Results are given as means \pm SE. Comparisons were performed by using Student's $t$-test, paired or unpaired. Multiple comparisons were statistically evaluated by using one-way ANOVA with the Dunnett $t$-test for pairwise analysis (Ussing chamber data) or the Holm-Sidak pairwise post hoc analysis (microelectrode data); $P$ values $<0.05$ were considered significant. $N$ refers to the number of experimental animals, and $n$ refers to the number of tissues in the treatment group.

\section{RESULTS}

\section{Flux Measurements in the Ussing Chamber}

Effect of SCFA and $\mathrm{CO}_{2}$ on urea flux at $\mathrm{pH}$ 7.4. Urea flux rates in both directions under control conditions $(\mathrm{pH} 7.4$ on both sides of the epithelium; $1 \mathrm{mmol} / \mathrm{l}$ urea) ranged from 19 to $35 \mathrm{nmol} \cdot \mathrm{cm}^{-2} \cdot \mathrm{h}^{-1}$ (see Table 1). No significant effect of SCFA on the magnitude of the flux rates could be found. $\mathrm{CO}_{2}$ had a slightly stimulating effect on urea transport (Table 2).

Theoretically, urea flux might occur via simple diffusion through the paracellular pathway, $G_{p}$, which accounts for some $60 \%$ of the transepithelial conductance $\left(G_{t}\right)$ in rumen epithelium (43). However, our results did not reveal a significant correlation $\left(r^{2}=0.09\right)$ between $\mathrm{G}_{\mathrm{t}}$ and serosal to mucosal $\left(J_{\text {sm }}\right)$ urea flux (Fig. 1), and no correlation was found between urea and mannitol fluxes as markers for paracellular transport (Fig. 2).

Mucosal to serosal $\left(J_{\mathrm{ms}}\right)$ and $J_{\mathrm{sm}}$ urea flux rates were not significantly different and, hence, no net transport was observed supporting a passive transport mechanism. In agreement with this, the $J_{\mathrm{sm}}$ showed a linear correlation to the serosal concentration of urea (Fig. 3).

These results suggest that transruminal urea transport is driven by the concentration gradient only and must occur either via a transcellular route or via a paracellular pathway with specificity for urea over mannitol.
Effect of SCFA on urea flux at $p H<7.4$. The negligible effects of SCFA and $\mathrm{CO}_{2}$ on urea transport at a luminal $\mathrm{pH}$ of 7.4 in vitro suggest that addition of these fermentation products alone is not sufficient to induce the increase in urea flux observed postprandially in vivo $(65,87,90)$. Because fermentation of carbohydrates in the rumen and production of SCFA and $\mathrm{CO}_{2}$ are accompanied by a decrease in ruminal $\mathrm{pH}$, which is thus typically lower than 7.4, we decided to change the $\mathrm{pH}$ of the mucosal solutions accordingly. Whereas a change of $\mathrm{pH}$ alone had no impact on urea transport, a reduction of $\mathrm{pH}$ from 7.4 to 6.4 in the presence of SCFA resulted in a significant fourfold increase in both $J_{\mathrm{ms}}$ and $J_{\mathrm{sm}}$ urea flux rates across the rumen epithelium (Table 3 and Fig. 3).

The effect of reducing mucosal $\mathrm{pH}$ in the presence of SCFA was so large that we decided to study the effect of lowering luminal $\mathrm{pH}$ in more detail, within the $\mathrm{pH}$ range from 7.4 to 5.4. The $J_{\mathrm{sm}}$ urea flux exhibited a bell-shaped dependency on mucosal $\mathrm{pH}$ with a maximum at $\sim \mathrm{pH} 6.2$, returning to the prestimulated level at a mucosal $\mathrm{pH}<5.8$ (Fig. 4).

Effect of $\mathrm{CO}_{2} / \mathrm{HCO}_{3}^{-}$on urea flux. In the absence of SCFA and at $\mathrm{pH}$ 7.4, increasing $\mathrm{CO}_{2}$ tension from 5 to $10 \%$ caused a light but significant increase in urea transport (Table 4). In the presence of $5 \% \mathrm{CO}_{2}$, a reduction of the $\mathrm{pH}$ on the mucosal side from 7.4 to 6.4 significantly $(P<0.05)$ stimulated urea transport and resulted in two- to threefold increases in both $J_{\mathrm{ms}}$ and $J_{\mathrm{sm}}$ urea flux rates across the rumen epithelium. At $\mathrm{pH}$ 6.4, the increase of $\mathrm{CO}_{2}$ from 5 to $10 \%$ doubled the urea transport rates $(\mathrm{pH}$ 6.4; Table 4). Interestingly, a reduction of the mucosal $\mathrm{pH}$ from 7.4 to 6.4 also significantly $(P<0.05)$ enhanced the $J_{\mathrm{ms}}$ and net chloride $\left(J_{\text {net }}\right)$ transport across the rumen epithelium (Table 5; see DISCUSSION).

Effect of a combination of $\mathrm{CO}_{2} / \mathrm{HCO}_{3}^{-}$and SCFA on urea flux. The $\mathrm{pH}$-dependent stimulation of urea flux rates was of similar magnitude in the presence of SCFA (Table 3) or $\mathrm{CO}_{2}$ $\left(5 \% \mathrm{CO}_{2}\right.$; Table 4). The combined application of these two fermentation products caused a slight increase of urea flux rates at pH 7.4 (Table 6; see also Tables 1 and 2).

At $\mathrm{pH}$ 6.4, the combined application of both fermentation products led to a highly significant increase of urea transport from $34.61 \pm 3.78$ to $151.68 \pm 16.39 \mathrm{nmol} \cdot \mathrm{cm}^{-2} \cdot \mathrm{h}^{-1}$, indicating that the effects of these fermentation products were additive (compare Tables 3, 4, and 6). A decrease of serosal $\mathrm{pH}$

Table 5. Effect of mucosal $\mathrm{pH}$ on bidirectional chloride transport across the rumen epithelium in presence of $\mathrm{CO}_{2} / \mathrm{HCO}_{3}^{-}$

\begin{tabular}{cccccc}
\hline \hline Mucosal pH & $J_{\mathrm{ms}}^{\mathrm{Cl}}, \mathrm{nmol} \cdot \mathrm{cm}^{-2} \cdot \mathrm{h}^{-1}$ & $J_{\mathrm{sm}}^{\mathrm{Cl}}, \mathrm{nmol} \cdot \mathrm{cm}^{-2} \cdot \mathrm{h}^{-1}$ & $J_{\mathrm{net}}^{\mathrm{Cl}}, \mathrm{nmol} \cdot \mathrm{cm}^{-2} \cdot \mathrm{h}^{-1}$ & $I_{\mathrm{sc}}, \mu \mathrm{eq} \cdot \mathrm{cm}^{-2} \cdot \mathrm{h}^{-1}$ & $\mathrm{G}_{\mathrm{t}}, \mathrm{mS} / \mathrm{cm}^{2}$ \\
\hline pH 7.4 & $3.7 \pm 0.6^{*}$ & $2.3 \pm 0.3$ & $1.3 \pm 0.3^{*}$ & $1.1 \pm 0.1$ & $3.3 \pm 0.3$ \\
pH 6.4 & $5.9 \pm 0.6 \dagger$ & $2.6 \pm 0.1$ & $3.2 \pm 0.4 \dagger$ & $1.1 \pm 0.1$ & $3.1 \pm 0.2$ \\
\hline
\end{tabular}

Values are means \pm SE. $J_{\mathrm{ms}}^{\mathrm{Cl}}$, mucosal-to-serosal chloride flux rate; $J_{\mathrm{sm}}^{\mathrm{Cl}}$, serosal-to-mucosal chloride flux rate; $J_{\text {net }}^{\mathrm{Cl}}$, net chloride transport. $N=$ number of animals; $n=$ number of tissues. Values in the same column bearing different symbols are significantly different at $P<0.05$ (paired $t$-test). 
Table 6. Effect of pH (mucosal or serosal) on urea flux rates across the rumen epithelium in presence of $\mathrm{CO}_{2}$ and SCFA

\begin{tabular}{lcccrr}
\hline \hline \multicolumn{1}{c}{$\mathrm{pH}$} & $J_{\mathrm{ms}}^{\text {urea }}, \mathrm{nmol} \cdot \mathrm{cm}^{-2} \cdot \mathrm{h}^{-1}$ & $J_{\mathrm{sm}}^{\text {urea }}, \mathrm{nmol} \cdot \mathrm{cm}^{-2} \cdot \mathrm{h}^{-1}$ & $J_{\text {net }}^{\text {urea }}, \mathrm{nmol} \cdot \mathrm{cm}^{-2} \cdot \mathrm{h}^{-1}$ & $I_{\mathrm{sc}}, \mu \mathrm{eq} \cdot \mathrm{cm}^{-2} \cdot \mathrm{h}^{-1}$ & $\mathrm{G}_{\mathrm{t}}, \mathrm{mS} / \mathrm{cm}^{2}$ \\
\hline Mucosal and serosal pH 7.4 & $34.6 \pm 3.7$ & $26.1 \pm 1.9$ & $8.4 \pm 3.2$ & $1.1 \pm 0.1$ & $3.1 \pm 0.1$ \\
Mucosal pH 6.4 & $151.6 \pm 16.3 *$ & $155.0 \pm 15.6^{*}$ & $-03.3 \pm 16.4$ & $0.9 \pm 0.1$ & $2.2 \pm 0.1 *$ \\
Serosal pH 6.4 & $38.4 \pm 5.0$ & $46.4 \pm 7.8^{*}$ & $-8.0 \pm 6.3 *$ & $0.9 \pm 0.1$ & $2.8 \pm 0.3$ \\
\hline
\end{tabular}

Values are means \pm SE. $N=$ number of animals; $n=$ number of tissues. $* P<0.05$ (Dunnett's $t$-test) compared with control (pH 7.4).

to 6.4 caused only a slight $\left(J_{\mathrm{sm}}\right)$ or no increase $\left(J_{\mathrm{ms}}\right)$ of urea transport (Table 6). Notably, a reduction of the mucosal $\mathrm{pH}$ had no effect on mannitol fluxes (Table 7).

Thus changes of mucosal (extracellular) $\mathrm{pH}$ in a buffer solution without SCFA and $\mathrm{CO}_{2} / \mathrm{HCO}_{3}^{-}$have no effect on urea transport. The effect of mucosal $\mathrm{pH} 6.4$ on urea transport depends on the presence of the fermentation products $\mathrm{CO}_{2}$ and SCFA, which are known to increase $\mathrm{Na}$ transport via $\mathrm{Na}^{+} / \mathrm{H}^{+}$ exchange (NHE) (26), thus indicating a change of intracellular $\mathrm{pH}\left(\mathrm{pH}_{\mathrm{i}}\right)$. Therefore, this change of $\mathrm{pH}_{\mathrm{i}}$ might modulate urea flux. Further experiments were designed to examine this assumption.

Effect of amiloride on urea flux at $p H$ 7.4. The presence of the protein involved in sodium-proton exchange (NHE) in ruminal epithelium is well documented $(2,22,27,31,74)$, and SCFA are known to stimulate this pH-regulating transport protein in the rumen $(25,76)$. If urea transport is mediated by changes in cytosolic $\mathrm{pH}$, inhibition of NHE should lead to measurable effects.

At a $\mathrm{pH}$ of 7.4, the $J_{\mathrm{sm}}$ flux of urea rose with the concentration of amiloride, in agreement with this hypothesis (Fig. 5). In a second step, the effect of the NHE inhibitor amiloride on urea fluxes was studied at $\mathrm{pH} 6.4$ and in the presence of SCFA. Interestingly, at this $\mathrm{pH}, 1 \mathrm{mmol} / \mathrm{l}$ mucosal amiloride significantly reduced urea flux (Table 3 ).

Effect of theophylline on the stimulated urea flux by SCFA at $p H$ 7.4. Theophylline is known to reduce the mucosal to serosal transport of sodium via NHE in the rumen (25). The effects of theophylline (Table 8) on urea transport ( $\mathrm{pH} 7.4)$ were similar to those of amiloride.

Effect of phloretin on urea flux. Phloretin reportedly has inhibitory effects on urea transport when applied both mucosally and serosally $(68,83)$. In this study, we confirmed the effects of serosal phloretin $(1 \mathrm{mmol} / \mathrm{l})$, which reduced urea transport $\left(J_{\mathrm{sm}}\right)$ by almost $50 \%$ [from $148.2 \pm 15.0$ to $75.8 \pm$ $8.8 \mathrm{nmol} \cdot \mathrm{cm}^{-2} \cdot \mathrm{h}^{-1}, n=6, N=2, P=0.002$ (paired Student's $t$-test)].

Effect of clamping transepithelial potential. Previous studies of urea transport in the inner medullary collecting duct of rat kidney have demonstrated $\mathrm{Na}^{+}$-linked urea transport (40). Since a number of studies have shown that, despite saturation kinetics, electrogenic cotransporters are responsive to changes

Table 7. Effect of decreasing mucosal $p H$ on the serosal to mucosal urea and mannitol fluxes across the rumen epithelium in presence of SCFA and $\mathrm{CO}_{2}$

\begin{tabular}{cccc}
\hline \hline Mucosal $\mathrm{pH}$ & $J_{\mathrm{sm}}^{\text {urea }}, \mathrm{nmol} \cdot \mathrm{cm}^{-2} \cdot \mathrm{h}^{-1}$ & $J_{\mathrm{sm}}^{\text {mannitol }}, \mathrm{nmol} \cdot \mathrm{cm}^{-2} \cdot \mathrm{h}^{-1}$ & $N / n$ \\
\hline 7.4 & $20.8 \pm 1.3$ & $4.7 \pm 0.3$ & $3 / 18$ \\
6.4 & $135.4^{*} \pm 5.1$ & $4.6 \pm 0.3$ & $3 / 18$ \\
\hline
\end{tabular}

Values are means \pm SE. $N=$ number of animals; $n=$ number of tissues. $* P<0.05$ (paired $t$-test vs. $\mathrm{pH} 7.4$ ). in potential, we tried to detect corresponding effects in the ruminal epithelium. However, changes in the $\mathrm{PD}_{t}$ in the Ussing chamber did not significantly influence urea flux rates (Table 9). Likewise, the addition of 1 or $7 \mathrm{mmol} / \mathrm{l}$ urea did not alter the electrical parameters of the rumen epithelium $\left(\mathrm{PD}_{\mathrm{t}}, \mathrm{G}_{\mathrm{t}}\right.$, and $I_{\mathrm{sc}}$; data not shown).

\section{Patch-Clamp Measurements}

Likewise, whole cell patch-clamp experiments performed on isolated ruminal epithelial cells did not reveal urea-dependent currents when $30 \mathrm{mmol} / \mathrm{l}$ mannitol was exchanged for the same amount of urea at either $\mathrm{pH} 7.4$ or $\mathrm{pH} 6.4(n=9)$ in the presence of sodium (Fig. 6). The influx of $\mathrm{Na}^{+}$coupled to urea should have led to an increase of inward current coupled to a depolarization of the cells, neither of which could be demonstrated.

In conclusion, these experiments do not support the hypothesis that urea transport of the ruminal epithelium is mediated by an electrogenic transport mechanism.

\section{Microelectrode Experiments}

The following experiments were performed to assess directly whether the ruminal epithelium possesses a $\mathrm{pH}$ microclimate and whether the $\mathrm{pH}$ within the transporting layer of the intact ruminal epithelium is altered by the addition of SCFA at a $\mathrm{pH}$ of 6.4 .

Measurement of apical $\mathrm{pH}$. After a brief $\mathrm{pH}$ calibration pulse (see MATERIALS AND METHODS) and a return of the bath

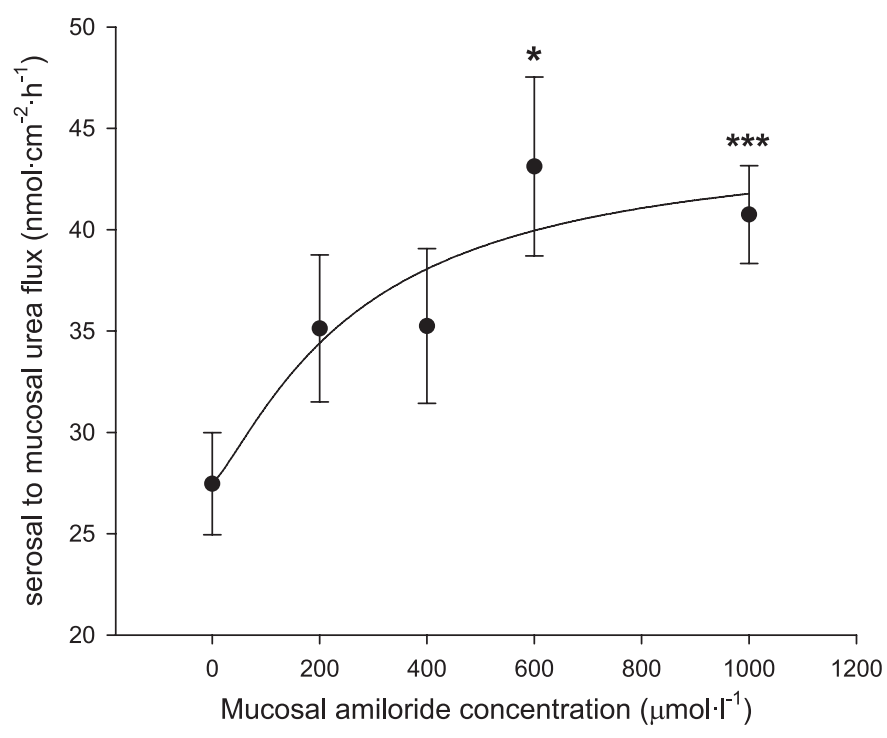

Fig. 5. Effect of increasing amiloride concentration on the mucosal side at $\mathrm{pH}$ 7.4 on $J_{\mathrm{sm}}$ urea flux across the rumen epithelium of sheep in the presence of SCFA $[N=3 ; n=8, * P<0.05 ; * * * P<0.001$ vs. $0 \mathrm{mmol} / 1$ amiloride (paired $t$-test)]. 
Table 8. Effect of theophylline $(10 \mathrm{mmol} / \mathrm{l})$ on urea flux rates across the rumen epithelium in presence of SCFA (pH 7.4 without $\mathrm{HCO}_{3}^{-}$)

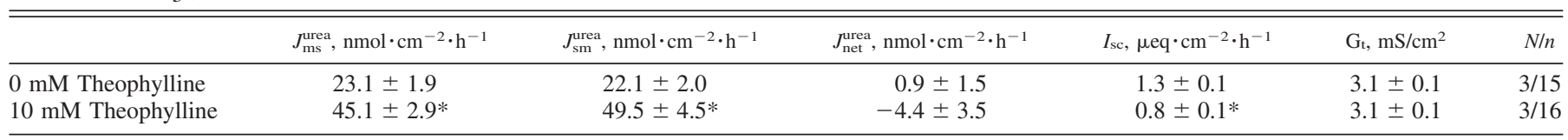

Values are means \pm SE. $N=$ number of animals; $n=$ number of tissues. $* P<0.05$ (unpaired $t$-test vs. 0 mM Theophylline).

perfusion to the original solution, the pipette was lowered onto the epithelium with a micromanipulator. A drop in $\mathrm{pH}$ from 7.4 to $7.2 \pm 0.5(P=0.05, n=7$, Holm-Sidak $)$ signaled the proximity of the transporting layer of cells (Fig. 7). At this point of the measurement, the potential of the reference electrode did not change notably and the response to transepithelial voltage pulses remained negligible. The initial $\mathrm{pH}$ response probably reflected the entry of the microelectrode into the stratum corneum, which is thought to form a $\mathrm{pH}$ microclimate (compare Ref. 45).

Measurement of cytosolic $\mathrm{pH}$. Impalement of the transporting syncytium (32) was considered to have occurred when the apical potential dropped and the response of the electrode to a transepithelial $10-\mathrm{mV}$ voltage pulse increased [from $0 \%$ to $50 \pm$ $10 \%$ (Fig. 7)]. Following impalement, the cytosolic $\mathrm{pH}$ was $7.08 \pm 0.09[n=7, P=0.002$ vs. $\mathrm{pH}$ of bulk solution (7.4) and $P=0.06$ vs. $\mathrm{pH}$ microclimate, Holm-Sidak]. Cytosolic $\mathrm{pH}$ remained relatively stable with a mean drift at $-0.03 \pm 0.02$ $\mathrm{pH} / \mathrm{min}$.

When mucosal perfusion was switched to a solution with a $\mathrm{pH}$ of 6.4 , cytosolic $\mathrm{pH}$ showed a slow decline $(-0.05 \pm 0.02$ $\mathrm{pH} / \mathrm{min})$, reaching $6.8 \pm 0.2(n=7, P=0.004$ vs. original level, Holm-Sidak) (Figs. 7, 8, and 9). Following the addition of SCFA ( $40 \mathrm{mmol} / \mathrm{l})$ to both sides of the epithelium, the rate of acidification increased markedly (to $-0.10 \pm 0.01 \mathrm{pH} / \mathrm{min}$, $P=0.02$ vs. rate of acidification at $\mathrm{pH} 6.4$ before addition of SCFA) with cytosolic $\mathrm{pH}$ dropping to $6.60 \pm 0.15(n=5)$. Return to a $\mathrm{pH}$ of 7.4 resulted in a recovery of $\mathrm{pH}_{\mathrm{i}}$ to $6.9 \pm 0.1$ $[+0.17 \pm 0.08 \mathrm{pH} / \mathrm{min}, P=0.005$ vs. previous (HolmSidak)].

These data thus confirm the presence of an apical microclimate above the transporting layer of cells $(24,45,75,93)$. Lowering the mucosal $\mathrm{pH}$ has slow acidifying effects on the cytosolic $\mathrm{pH}$. The rate of acidification increases significantly when SCFA are added to the solution.

\section{DISCUSSION}

This study represents the first clear demonstration of a $\mathrm{pH}$-dependent short-term regulation of a mammalian urea transporter $(6,81)$, with possible consequences for in vivo situations. Moreover, the data presented here significantly enhance our understanding of ruminal urea transport by the demonstration of a number of new findings. 1) We demonstrate that ruminal urea transport cannot be explained by paracellular diffusion and thus enhance the argument for a transcellular passage via a specific protein such as UT-B $(49-51,68,69,80$, 83). 2) Effects of SCFA and $\mathrm{CO}_{2}$ on urea transport are absent or of quantitatively minor importance at $\mathrm{pH}$ 7.4. 3) In the presence of SCFA or $\mathrm{CO}_{2}$ and within the $\mathrm{pH}$ range of $6.00-$ 7.00 , urea transport rates are increased by lowering mucosal pH. 4) At a mucosal $\mathrm{pH}$ of $<6.00$, the addition of SCFA inhibits urea transport. 5) Transruminal urea transport is stimulated by amiloride at a $\mathrm{pH}$ of 7.4 , whereas at a $\mathrm{pH}$ of 6.4 amiloride has inhibitory effects.

In addition, the data confirm the presence of an apical $\mathrm{pH}$ microclimate and directly demonstrate the acidifying effects of the application of SCFA on the $\mathrm{pH}_{\mathrm{i}}$ of the underlying transporting epithelium.

\section{Ruminal Urea Transport Is Passive and Sensitive to Phloretin}

The transport of urea across the rumen epithelium is generally accepted to be driven by the concentration gradient between blood plasma and ruminal fluid with permeability being strongly limited by the stratum corneum $(38,89)$. The absence of significant urea net transport and the close correlation between the serosal urea concentration and $J_{\mathrm{sm}}$ urea are in agreement with this assumption (Fig. 3). In our study, no correlation could be seen between $J_{\mathrm{sm}}$ urea and the $\mathrm{G}_{\mathrm{t}}$ of the isolated rumen epithelium (Fig. 1) or mannitol fluxes (Fig. 2). A transcellular pathway for urea transport is supported by the $\mathrm{pH}$-dependent increase of urea flux without any effect on mannitol fluxes (Table 7) and by the inhibition of urea transport by phloretin in this study and in others $(68,69,83)$. Our hypothesis of a transcellular pathway agrees well with the urea transporters (UT-B) demonstrated in the plasma membranes of all cell layers of the bovine rumen epithelium, with the exception of the stratum corneum (83). However, we were unable to confirm the close correlation between mannitol and urea fluxes found in the same study (83). Both edge damage and speciesdependent differences may have contributed to what would appear to be a larger paracellular "leak" of the bovine tissues studied by Stewart et al. (83), but such speculation is problematic, since the authors do not report values for $\mathrm{G}_{\mathrm{t}}$.

Table 9. Effect of transepithelial potential difference on bidirectional urea flux rates across the rumen epithelium at a mucosal pH of 6.4 in presence of SCFA and $\mathrm{CO}_{2} / \mathrm{HCO}_{3}^{-}$

\begin{tabular}{ccccrr}
\hline \hline Transepithelial Potential & $J_{\mathrm{sm}}^{\text {urea }}, \mathrm{nmol} \cdot \mathrm{cm}^{-2} \cdot \mathrm{h}^{-1}$ & $J_{\mathrm{ms}}^{\text {urea }}, \mathrm{nmol} \cdot \mathrm{cm}^{-2} \cdot \mathrm{h}^{-1}$ & $J_{\text {net }}^{\text {urea }}, \mathrm{nmol} \cdot \mathrm{cm}^{-2} \cdot \mathrm{h}^{-1}$ & $I_{\mathrm{sc}}, \mu \mathrm{eq} \cdot \mathrm{cm}^{-2} \cdot \mathrm{h}^{-1}$ & $\mathrm{G}_{\mathrm{t}}, \mathrm{mS} / \mathrm{cm}^{2}$ \\
\hline $0 \mathrm{mV}$ & $134.2 \pm 11.8$ & $122.1 \pm 8.4$ & $12.1 \pm 12.4$ & $1.1 \pm 0.1$ & $2.9 \pm 0.2$ \\
$+25 \mathrm{mV}$ & $125.3 \pm 12.9$ & $130.0 \pm 11.0$ & $-4.6 \pm 8.4$ & $0.5 \pm 0.1 *$ & $2.7 \pm 0.1$ \\
$-25 \mathrm{mV}$ & $132.2 \pm 7.5$ & $116.2 \pm 7.7$ & $15.9 \pm 7.7$ & $3.0 \pm 0.1 *$ & $2 / 6$ \\
\hline
\end{tabular}

Values are means \pm SE. $N=$ number of animals; $n=$ number of tissues. $* P<0.05$ (Dunnett's $t$-test) vs. control $(0 \mathrm{mV})$. 
A

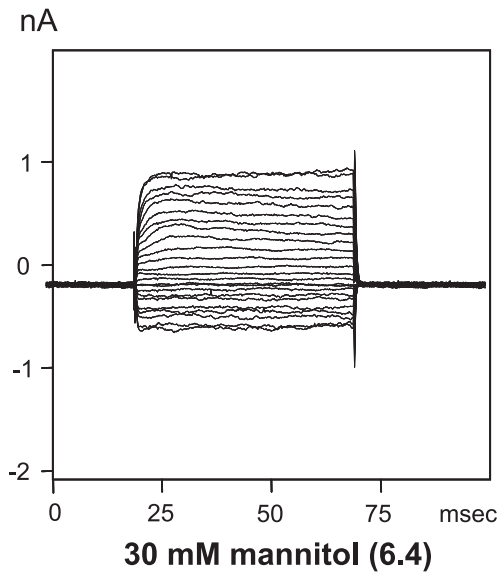

B

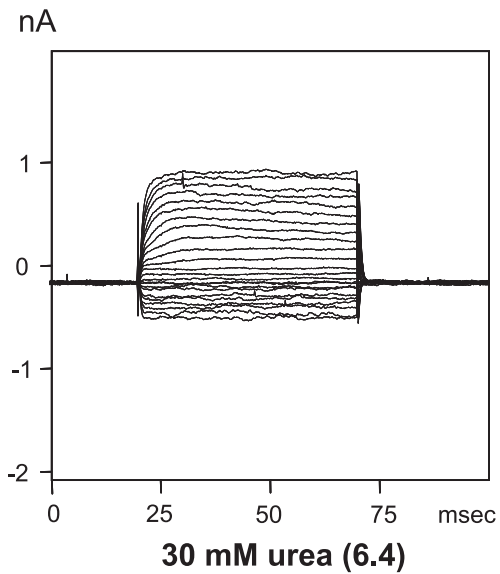

Fig. 6. Original traces of a ruminal epithelial cell filled with a physiological K-gluconate solution and exposed to Ringer's solution containing $30 \mathrm{mmol} / \mathrm{l}$ of mannitol $(A)$ and $30 \mathrm{mmol} / \mathrm{l}$ urea $(B)$. No effects could be detected.

\section{Luminal pH Is a Decisive Cofactor for the Effects of $\mathrm{SCFA} / \mathrm{CO}_{2}$ on Urea Transport}

Given the well-documented and major impact of fermentation on urea transport across the rumen in vivo, we were initially surprised to find only insignificant (SCFA) or small $\left(\mathrm{CO}_{2}\right)$ effects of these fermentation products on urea transport across the isolated epithelium under standard conditions in the Ussing chamber. However, a $\mathrm{pH}$ of 7.4 is unusually high for in vivo conditions and is more typical of fasting animals in which the rate of fermentation is slow. In these situations, the backflow of urea into the gut approaches zero, despite an increase in the level of urea in plasma (35). Conversely, the highest rates of urea influx into the rumen are observed postprandially, when fermentational processes lead to a drop in ruminal $\mathrm{pH}(63,64)$. However, in this study, the lowering of luminal $\mathrm{pH}$ alone merely had minor effects on urea flux (Table 3). Only after the physiological situation was simulated more completely by the addition of $\mathrm{CO}_{2}$ at a $\mathrm{pH}$ of 6.4 were we able to see large stimulatory effects on urea flux (Tables 3, 4, and 6), corresponding to the well-documented effects observed in vivo $(35,65,87,90)$. Similar effects were seen with SCFA.
Interestingly, a stepwise reduction of $\mathrm{pH}$ in the presence of SCFA (without $\mathrm{CO}_{2}$ ) from 7.4 to 5.4 led to a bell-shaped modification of urea transport (Fig. 4). Transport rates were low at $\mathrm{pH} 7.4$ and $\mathrm{pH} 7.0$, rising to maximal levels at around $\mathrm{pH} 6.2$, followed by a steep drop to the original level when $\mathrm{pH}$ was lowered to $<5.8$. This bell-shaped dependency may be one of many possible reasons why in vivo studies of the stimulation of urea transport by SCFA have produced conflicting results $(65,87,90)$.

Physiologically, the meaning of this finding is evident: in fasting animals, the influx of urea with subsequent hydrolysis by ruminal urease $(9,63)$ leads to an increase in ruminal ammonia concentration. Free ammonia, however, is rapidly absorbed back into the portal system (1) and must again be detoxified in the liver. Thus a reduction of urea recycling (35) can be seen as an adaptational response that is beneficial to the fasting animal. Conversely, postprandial stimulation of urea transport into the rumen by fermentation products, as demonstrated in vivo in previous investigations $(63,65-67,87,90)$ and in vitro in this study, ensures that the influx of urea into the rumen is tightly linked to the nitrogen requirements of a growing microbial population.

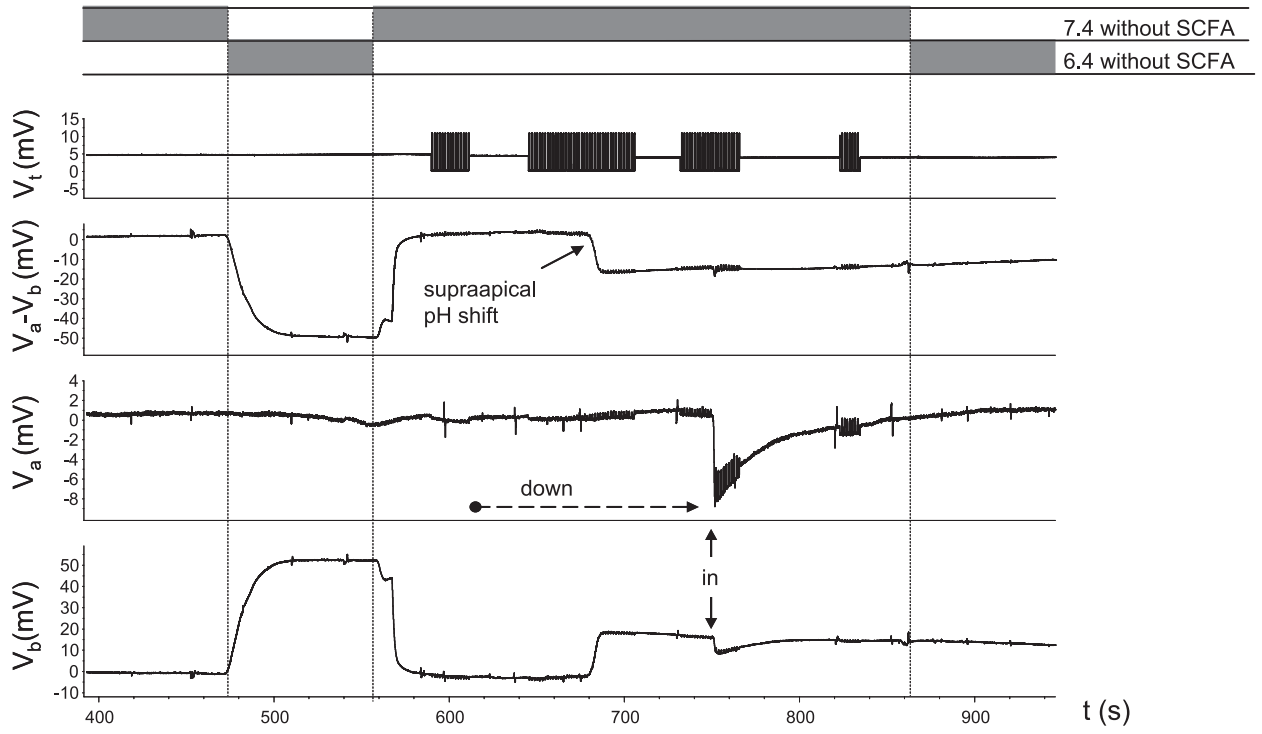

Fig. 7. Original recording showing the transepithelial potential $\left(\mathrm{V}_{\mathrm{t}}\right)$, the potential of the $\mathrm{pH}-$ insensitive electrode $\left(\mathrm{V}_{\mathrm{a}}\right)$, the $\mathrm{pH}$-sensitive electrode $\left(\mathrm{V}_{\mathrm{b}}\right)$, and the difference between the 2 $\left(\mathrm{V}_{\mathrm{a}}-\mathrm{V}_{\mathrm{b}}\right)$ over time. For calibration, the doublebarrelled electrode was positioned in the bath well above the tissue and the mucosal bath solution was switched from $\mathrm{pH} 7.4$ to $\mathrm{pH} 6.4$ and back again, resulting in a marked change in the potential of $\mathrm{V}_{\mathrm{b}}$, but not of $\mathrm{V}_{\mathrm{a}}$. The electrode was moved downward slowly. A pH shift toward a more acidic value ("supra-apical $\mathrm{pH}$ shift") could be seen before the electrode entered the epithelium (in). Note the drop in the potential of $\mathrm{V}_{\mathrm{a}}$ and $\mathrm{V}_{\mathrm{b}}$ and the rise in the fractional apical resistance as measured by the response of the electrode to transepithelial voltage pulses. $t$, Time. 
Fig. 8. Original recording showing the response of an impaled microelectrode to a change in mucosal $\mathrm{pH}$ to 6.4 and the addition of SCFA at SCFA-free solution at $\mathrm{pH}$ 7.4. The first arrow designates the beginning of the impalement (in) corresponding to a shift in the potential of both electrodes, whereas the second arrow (out) reflects the end of the impalement (brought about by elevating the electrode). Calibration of the electrode was performed before and after impalement. The measurement was performed in the open circuit mode but the transepithelial potential was clamped briefly $(0.3 \mathrm{~s})$ at various points to measure the epithelial conductance (2.9 $\left.\mathrm{mS} / \mathrm{cm}^{2}\right)$ and fractional apical resistance $(\sim 70 \%)$. $\mathrm{pH}$ 6.4, followed by recovery after return to a

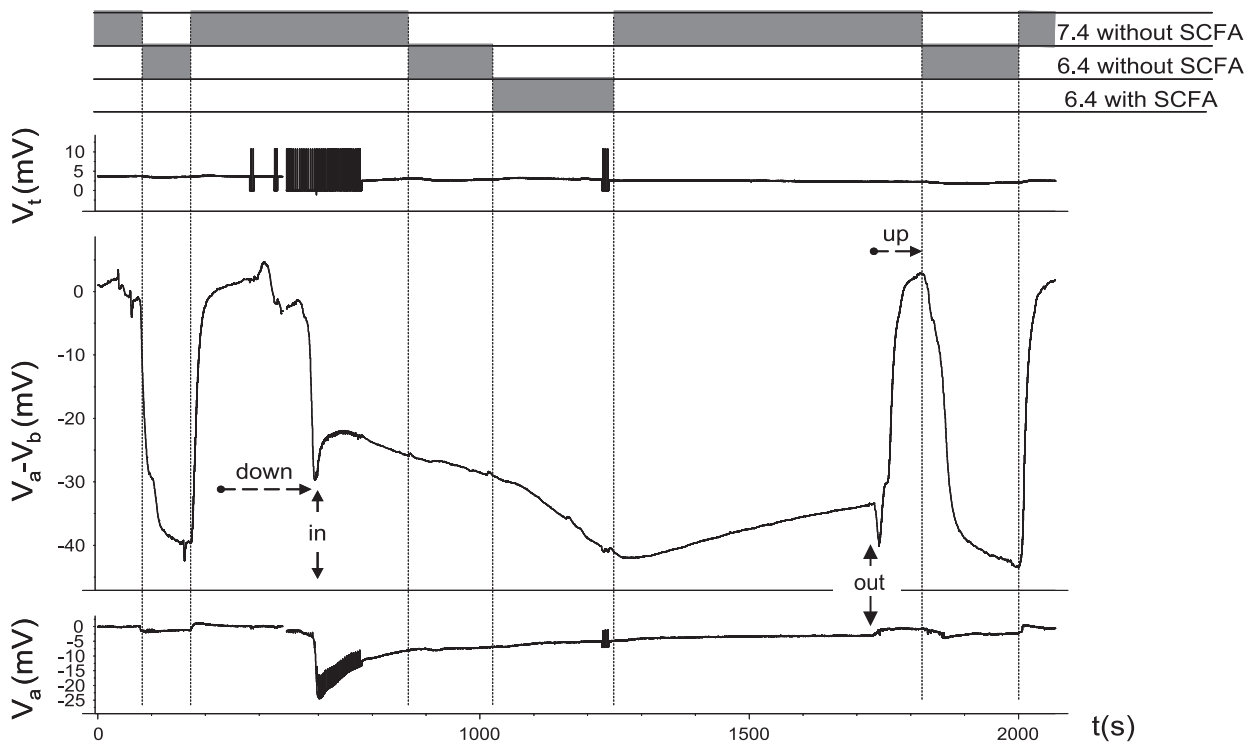

Likewise, the inhibition of urea transport at a luminal $\mathrm{pH}$ of $<6.0$ may be of significant practical importance. Thus the attempt to raise urea recycling by increasing intraruminal fermentation with the production of $\mathrm{CO}_{2}$ and SCFA by feeding highly fermentable carbohydrates can result in failure (30), which is to be expected since ruminal $\mathrm{pH}$ frequently drops to values below 5.7 under these conditions. Feeding conditions with low ruminal $\mathrm{pH}$ values can therefore be expected to reduce the use of endogenous urea-N for the synthesis of microbial protein on the one hand, whereas, on the other hand, urea excretion via urine is increased with an adverse environmental impact.

\section{Effect of Theophylline and Amiloride on Urea Transport}

The stimulatory effect of theophylline (Table 8) might lead to the false conclusion that the signaling cascade leading to the activation of urea flux into the rumen is linked to a cAMPdependent pathway (10). However, UT-A does not appear to be expressed by the ruminal epithelium (83), whereas transporters from the UT-B group typically do not show cAMP-mediated phosphorylation $(6,81,83)$. Instead, we have shown that amiloride has similar effects on urea transport as theophylline (Fig. 5). Both agents have been demonstrated to suppress electroneutral sodium transport via $\operatorname{NHE} 3(25,56,94)$. Conversely, at pH 6.4, amiloride inhibits urea transport. We suggest that all the effects observed in this study are mediated by changes in cytosolic pH (compare Fig. 4).

\section{Na and Urea Transport}

The possibility of an active transport of urea was discussed in the past $(16,28,29)$, although this possibility was ruled out in later studies that failed to demonstrate saturation kinetics $(38,89) . \mathrm{Na}^{+}$-linked urea transporters have been identified in a number of mostly amphibian epithelia (70), mediating both $\mathrm{Na}^{+}$-urea cotransport and $\mathrm{Na}^{+}$-urea antiport. Any $\mathrm{Na}^{+}$-linked urea transport should be uncovered by changing the driving forces of luminal $\mathrm{Na}^{+}$uptake in the Ussing chamber. The
Fig. 9. Original recording showing the potential of an impaled double-barrelled microelectrode over time and in response to various experimental solutions, followed by an extracellular calibration (after out). Note that addition of SCFA resulted in a much stronger acidification than a change in $\mathrm{pH}$ alone. After removal of SCFA, recovery of intracellular $\mathrm{pH}$ was observed even when extracellular $\mathrm{pH}$ remained at 6.4. As before, the transepithelial potential was occasionally clamped to measure the fractional apical resistance $(\sim 80 \%)$ and tissue conductance $\left(2.7 \mathrm{mS} / \mathrm{cm}^{2}\right)$.

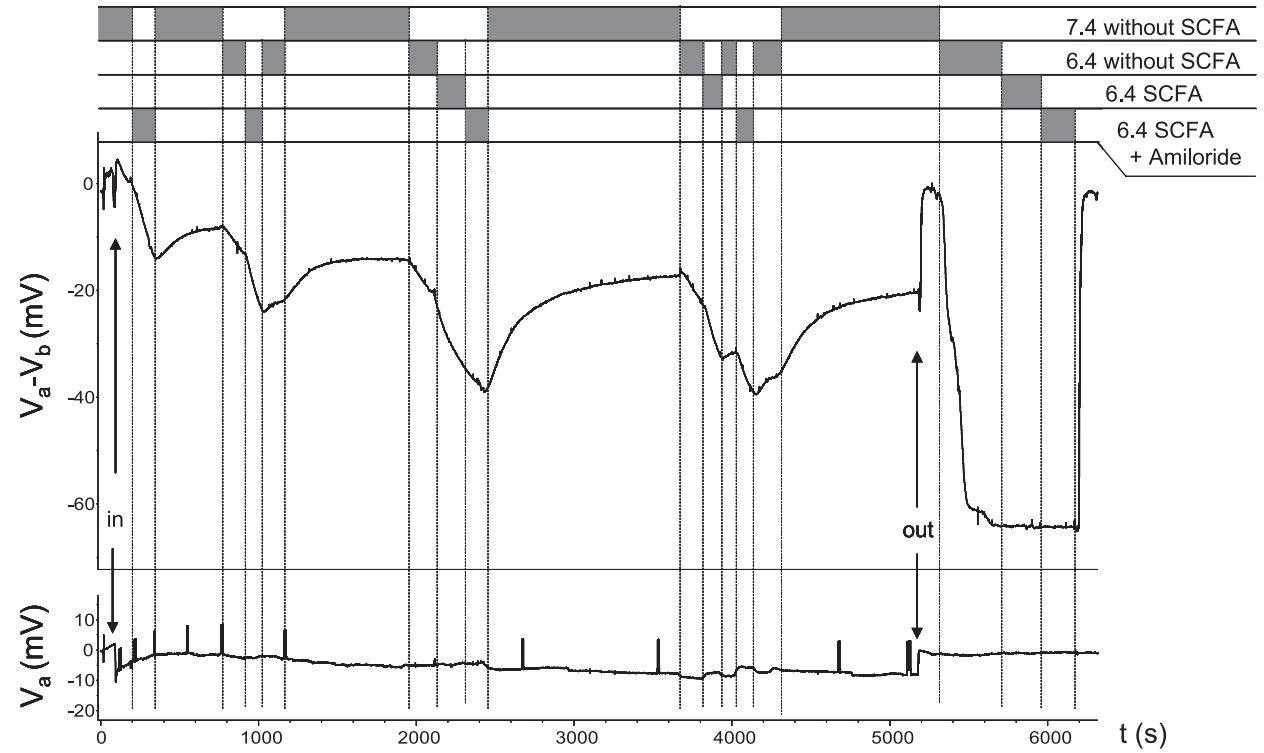

AJP-Gastrointest Physiol • VOL 298 FEBRUARY 2010 • www.ajpgi.org 
change of transepithelial potential difference $( \pm 25 \mathrm{mV})$, which alters the potential difference of the apical membrane by \pm 15 $\mathrm{mV}$ (43), does not influence urea transport and argues against $\mathrm{Na}^{+}$-urea cotransport (Table 9).

Whereas the evidence argues against the direct coupling of $\mathrm{Na}^{+}$and urea transport, both transport rates appear to be regulated in a similar fashion. The experimental conditions that caused the increase of urea transport in this study (Tables 3, 4, and 6; Fig. 4) are similar to those in corresponding studies in which the stimulatory effect of these fermentation products on amiloride-sensitive $\mathrm{Na}^{+}$absorption via NHE has been characterized $(24,26,53,54,77)$. As in monogastric animals in which $\mathrm{Na}^{+}$uptake also increases in response to a change in the luminal end products of digestion (20), the underlying transporter is NHE3, an extremely well-characterized transport protein that utilizes the energy from the influx of $\mathrm{Na}^{+}$to drive the efflux of $\mathrm{H}^{+}$on a 1:1 basis, in allosterically regulated manner so that the extrusion of protons stops when the cytosolic $\mathrm{pH}$ reaches the set point optimal for cellular function $(3,20,91)$.

\section{Effect of SCFA and $\mathrm{CO}_{2}$ on the Transport of Urea}

$\mathrm{CO}_{2}$ caused a small concentration-dependent and significant increase of urea transport at $\mathrm{pH} 7.4$ and a marked enhancement at pH 6.4 (Table 4), with a simultaneous increase in $J_{\mathrm{ms}}$ and $J_{\text {net }}$ chloride flux rates (Table 5). Since the pressure of $\mathrm{CO}_{2}$ was constant in all of these experiments, the lowering of mucosal $\mathrm{pH}$ must have caused a decrease in luminal $\mathrm{HCO}_{3}^{-}$concentration, which promotes $\mathrm{HCO}_{3}^{-}$(base) extrusion and $\mathrm{Cl}^{-}$uptake. According to this classical model, this should be followed by the dissociation of cytosolic $\mathrm{CO}_{2}$ with acidification and stimulation of NHE $(12,54)$ and of the urea transporter of this study. In agreement with this hypothesis, the inhibition of carboanhydrase by acetazolamide (21) or the replacement of $\mathrm{CO}_{2}$ reduces electroneutral $\mathrm{Na}$ transport $(12,54)$. A similar coupled stimulation of both $\mathrm{Na}^{+}(24,26,53,54,77)$ and urea transport follows exposure of the tissue to SCFA. It thus appears likely that the $\mathrm{pH}$-dependent effects of amiloride, theophylline, $\mathrm{CO}_{2}$, and SCFA on both sodium $(24,26,53,54$, 77) and urea transport are mediated by the same central event: a change in cytosolic $\mathrm{pH}$.

\section{Effect of SCFA on the Intraepithelial $p H$ of the Intact Ruminal Epithelium}

Some counterarguments can be raised against the hypothesis that cytosolic $\mathrm{pH}$ is altered after exposure of the epithelium to SCFA. Both diffusion of the protonated form (H-SCFA) (93) and uptake via $\mathrm{SCFA}^{-} / \mathrm{HCO}_{3}^{-}$exchange with dissociation of $\mathrm{CO}_{2}(5,24,78)$ should lead to an acidification of the cell $(78)$, as shown in isolated cells of the ruminal epithelium in vitro (8). However, if, in intact tissue, the influx of SCFA is mediated by an anion exchanger (5) physically linked to NHE3 via scaffolding proteins (20) or if an influx of SCFA ${ }^{-}$anions occurs primarily via an apical anion channel similar to that mediating the basolateral efflux of acetate (85), cytosolic $\mathrm{pH}$ should remain constant or show a slight increase. For this reason, we attempted to measure the cytosolic $\mathrm{pH}$ of the intact ruminal epithelium under the same conditions as those applied in the Ussing chamber directly by using $\mathrm{pH}$-sensitive microelectrodes.

The microelectrode experiments show surprisingly strong responses of the tissue to a lowering of mucosal $\mathrm{pH}$, even before the addition of SCFA. This may in part reflect the fact that the experiments were performed under the same standard conditions as those used in the flux experiments, with SCFA present bilaterally. It should also be noted that cell potential tended to decrease rapidly with time. This suggests that some damage to the tissue may have occurred during impalement by the microelectrode and that $\mathrm{pH}$ effects might be less pronounced in the Ussing chamber or in vivo. Despite this caveat, the microelectrode experiments show that, at a constant apical $\mathrm{pH}$ of 6.4, the addition of SCFA to the solution has an obviously acidifying effect on the $\mathrm{pH}_{\mathrm{i}}$ of the transporting cell layer (compare Figs. 8 and 9). Accumulation of protons within the cytosol thus clearly occurs more rapidly than the influx of $\mathrm{SCFA}^{-}$anions via a channel or via a major unspecific leak pathway. Whereas it appears likely that the $\mathrm{pH}$ regulatory response $(24,26,53,54,77)$ is more efficient under in vivo conditions, an influx of SCFA into the transporting syncytium of the ruminal epithelium (32) is evidently coupled to an increase in intracellular protons.

We consider it worth mentioning that the microelectrode data also support the presence of a $\mathrm{pH}$ microclimate over the transporting layer of cells (see Fig. 7). This finding is in agreement with a recent fluorescence study (45) and previous suggestions $(12,24)$. Most likely, the thick stratum corneum of the ruminal epithelium (32) creates an unstirred layer with a $\mathrm{pH}$ distinct from the bulk of the ruminal solution; this might play a role in the diffusional uptake of H-SCFA $(24,45,75,93)$.

\section{A Role for Cytosolic pH in Regulating Ruminal Urea Transport?}

To the knowledge of the authors, acute $\mathrm{pH}$-dependent effects on mammalian urea transporters have not previously been reported $(7,70,81,95)$, although a number of such transporters have been identified in bacteria or yeasts (7).

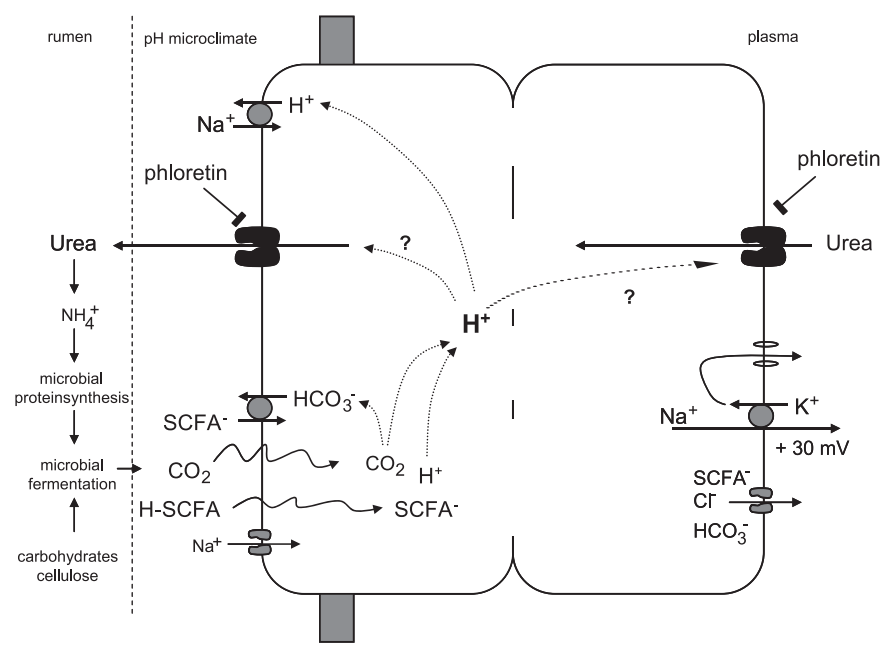

Fig. 10. Model of ruminal urea transport. Endogenous secretion of urea for microbial protein synthesis occurs transcellularly across the multilayered ruminal epithelium, crossing both the basolateral and apical membranes via phloretin-sensitive proteins that may belong to the urea transporter-B group. Secretion of urea into the rumen is highest when $\mathrm{CO}_{2}$ and SCFA are present and when the rumen $\mathrm{pH}$ is within a physiological range $\sim 6.2$, suggesting regulatory effects on the urea-transporting proteins. This mechanism might synchronize the growth of ruminal microbial populations with the availability of nutrients and the requirements of ruminal homeostasis (for details, see text). 
The present study suggests that a change in the cytosolic concentration of protons is a central signaling event that regulates the permeability of the rumen to urea via UT-B or another permeable urea-carrying protein as an immediate response to an increase in ruminal fermentation. In the simplest case, the transporter might be activated by intracellular protons through the formation of hydrogen bonds that induce conformational changes, as reported for bacterial urea transporters (7). A pH optimum may be necessary to protonate certain binding sites within the UT-B pore, configuring it for the passage of the urea molecule. An analogous situation has been reported for the CLC-2 chloride channel (57). The open probability of this channel is low at high values of $\mathrm{pH}$ but increases after acidification by protonation of a glutamine residue within the channel pore. When the $\mathrm{pH}$ decreases further to values below 7.0, the protonation of an extracellularly located histidine residue (with a near neutral $\mathrm{pK}$ value) closes the channel. This results in a biphasic activation-inactivation curve around the physiological $\mathrm{pH}$. Similar $\mathrm{pH}$-dependent effects are reported for the permeability of native chloride channels (4) and bacterial toxins (37). UT-B in the rumen could well be regulated in a similar fashion. However, we do not exclude the possibility that signaling may be far more complex and involve currently unknown pathways, such as sensors for acid or volume $(15,47)$.

\section{Functional Significance}

From the perspective of ruminal physiology, some speculation about the significance of these findings is possible: since the natural diet of the ruminant tends to be low in protein, increased rates of fermentation with rising bacterial populations require an additional influx of urea-nitrogen into the rumen for protein synthesis. Conversely, in situations in which ruminal $\mathrm{pH}$ (and in consequence, also cellular $\mathrm{pH}$ ) drops dangerously low, a decrease in urea influx into the rumen may lower the rate of bacterial growth and, thus, slow down fermentational processes with the release of acidic equivalents. Disturbance of this delicate balance might be one of the reasons that feeding regimes with the imposition of nutritional synchrony of protein and energy have not consistently generated the expected increases in animal productivity $(14,33)$. Interestingly, UT-B ${ }^{-1-}$ mice mutants display lower weight gain (95), suggesting that the fine-tuning of the urea flux into the gastrointestinal tract may also play a role in monogastric species.

A determination of whether the urea transporters of the erythrocyte (6) or of the descending limb of the vasa recta of the kidney (95) are regulated in the manner described here would be most interesting; this could be of significant importance given the $\mathrm{pH}$ drop along the renal vasa recta in conjunction with high levels of $\mathrm{CO}_{2}$ (42). The current consensus appears to be that UT-B is not regulated by short-term effects $(6,81)$, but we have been unable to find studies of UT-B regulation carried out under conditions that resemble those of this study.

\section{Model for the Regulation of Ruminal Urea Transport}

In conclusion, urea is transported across the rumen epithelium passively via phloretin-sensitive proteins that may well correspond to UT-B (Fig. 10). The well-documented positive effects of fermentation products on urea transport in vivo can be also be shown in vitro. The effects are predominantly $\mathrm{pH}$ dependent and only apply to the range of luminal $\mathrm{pH}$ from 7.0 to 6.2. At extremely high levels of intake, readily fermentable carbohydrates may therefore lead to a reduction in urea recycling to the rumen and increase the amount of urea excreted with the urine, while simultaneously elevating the amount of protein necessary to meet the nutritional requirements of the animal. A better understanding of the factors that increase and decrease the gastrointestinal recycling of urea in vitro and in vivo thus appears to be of central importance in reducing production costs and the release of nitrogen into the environment.

\section{ACKNOWLEDGMENTS}

K. Abdoun and I. Rabbani are recipients of scholarships from the Alexander-von-Humboldt Foundation (Georg Forster) and the Deutscher Akademischer Austausch Dienst (DAAD), respectively.

\section{GRANTS}

The study was support by grants from the Margarete-Markus Charity and the Wilhelm Schaumann Foundation.

\section{DISCLOSURES}

No conflicts of interest are declared by the author(s).

\section{REFERENCES}

1. Abdoun K, Stumpff F, Martens H. Ammonia and urea transport across the rumen epithelium: a review. Anim Health Res Rev 7: 43-59, 2006.

2. Abdoun K, Stumpff F, Wolf K, Martens H. Modulation of electroneutral $\mathrm{Na}$ transport in sheep rumen epithelium by luminal ammonia. Am J Physiol Gastrointest Liver Physiol 289: G508-G520, 2005.

3. Aronson PS, Nee J, Suhm MA. Modifier role of internal $\mathrm{H}^{+}$in activating the $\mathrm{Na}^{+}-\mathrm{H}^{+}$exchanger in renal microvillus membrane vesicles. Nature 299: 161-163, 1982.

4. Arreola J, Begenisich T, Melvin JE. Conformation-dependent regulation of inward rectifier chloride channel gating by extracellular protons. $J$ Physiol 541: 103-112, 2002.

5. Aschenbach JR, Bilk S, Tadesse G, Stumpff F, Gäbel G. Bicarbonatedependent and bicarbonate-independent mechanisms contribute to nondiffusive uptake of acetate in the ruminal epithelium of sheep. Am J Physiol Gastrointest Liver Physiol 296: G1098-G1107, 2009.

6. Bagnasco SM. The erythrocyte urea transporter UT-B. J Membr Biol 212: 133-138, 2006.

7. Bagnasco SM. Role and regulation of urea transporters. Pflügers Arch 450: 217-226, 2005

8. Bilk S. Mechanismen der anionischen SCFA-Resorption im Pansen des Schafes (PhD Thesis). Leipzig, Germany: Universität Leipzig, 2008.

9. Bloomfield R, Garner G, Muhrer M. Kinetics of urea metabolism in sheep. J Anim Sci 19: 1248, 1960.

10. Blount MA, Mistry AC, Frohlich O, Price SR, Chen G, Sands JM, Klein JD. Phosphorylation of UT-A1 urea transporter at serines 486 and 499 is important for vasopressin-regulated activity and membrane accumulation. Am J Physiol Renal Physiol 295: F295-F299, 2008.

11. Brahm J. Urea permeability of human red cells. J Gen Physiol 82: 1-23, 1983.

12. Chien WJ, Stevens CE. Coupled active transport of $\mathrm{Na}$ and $\mathrm{Cl}$ across forestomach epithelium. Am J Physiol 223: 997-1003, 1972.

13. Cocimano MR, Leng RA. Metabolism of urea in sheep. Br J Nutr 21: 353-371, 1967.

14. Cole NA, Todd RW. Opportunities to enhance performance and efficiency through nutrient synchrony in concentrate-fed ruminants. J Anim Sci 86: E318-E333, 2008.

15. Crichlow EC, Leek BF. Forestomach epithelial receptor activation by rumen fluids from sheep given intraruminal infusions of volatile fatty acids. Am J Vet Res 47: 1015-1018, 1986.

16. Decker P, Gärtner K, Hörnicke H, Hill H. Fortlaufende Messungen von Harnstoffbildung und Harnstoffrückfluss in den Pansen in Abhängigkeit 
vom Harnfluss mit Hilfe von ${ }^{14} \mathrm{C}$-Harnstoff bei Ziegen. Pflügers Arch 274: 289-294, 1961.

17. Deveau JS, Lindinger MI, Grodzinski B. An improved method for constructing and selectively silanizing double-barreled, neutral liquidcarrier, ion-selective microelectrodes. Biol Proced Online 7: 31-40, 2005.

18. Dihn SK. Urea-N Recycling in Lactating Dairy Cows (PhD Dissertation). College Park, MD: University of Maryland, 2007.

19. Dobson A, Sellers AF, Thorlacius SO. Limitation of diffusion by blood flow through bovine ruminal epithelium. Am J Physiol 220: 1337-1343, 1971.

20. Donowitz M, Li X. Regulatory binding partners and complexes of NHE3. Physiol Rev 87: 825-872, 2007.

21. Emanovic D, Harrison FA, Keynes RD, Rankin JC. The effect of acetazolamide on ion transport across isolated sheep rumen epithelium. $J$ Physiol 254: 803-812, 1976.

22. Etschmann B, Heipertz KS, von der Schulenburg A, Schweigel M. A $\mathrm{vH}^{+}$-ATPase is present in cultured sheep ruminal epithelial cells. Am J Physiol Gastrointest Liver Physiol 291: G1171-G1179, 2006.

23. Frömter E, Gebler B. Electrical properties of amphibian urinary bladder epithelia. III. The cell membrane resistances and the effect of amiloride. Pflügers Arch 371: 99-108, 1977.

24. Gäbel G, Aschenbach JR, Müller F. Transfer of energy substrates across the ruminal epithelium: implications and limitations. Anim Health Res Rev 3: 15-30, 2002.

25. Gäbel G, Butter H, Martens H. Regulatory role of cAMP in transport of $\mathrm{Na}^{+}, \mathrm{Cl}^{-}$and short-chain fatty acids across sheep ruminal epithelium. Exp Physiol 84: 333-345, 1999.

26. Gäbel G, Vogler S, Martens H. Short-chain fatty acids and $\mathrm{CO}_{2}$ as regulators of $\mathrm{Na}^{+}$and $\mathrm{Cl}^{-}$absorption in isolated sheep rumen mucosa. $J$ Comp Physiol [B] 161: 419-426, 1991.

27. Galfi P, Neogrady S, Gäbel G. $\mathrm{Na}^{+} / \mathrm{H}^{+}$exchange in primary, secondary and n-butyrate-treated cultures of ruminal epithelial cells: short communication. Acta Vet Hung 50: 211-215, 2002.

28. Gärtner K. Untersuchungen über den Transportmechanismus von Harnstoff-Stickstoff durch die Pansenschleimhaut von Rindern in vitro. Pflügers Arch 276: 292-302, 1962.

29. Gärtner K, Decker P, Hill H. Untersuchungen über die Passage von Harnstoff und Ammoniak durch die Pansenwand von Ziegen. Pflügers Arch 274: 281-288, 1961

30. Gozho GN, Hobin MR, Mutsvangwa T. Interactions between barley grain processing and source of supplemental dietary fat on nitrogen metabolism and urea-nitrogen recycling in dairy cows. J Dairy Sci 91: 247-259, 2008.

31. Graham C, Gatherar I, Haslam I, Glanville M, Simmons NL. Expression and localization of monocarboxylate transporters and sodium/proton exchangers in bovine rumen epithelium. Am J Physiol Regul Integr Comp Physiol 292: R997-R1007, 2007.

32. Graham C, Simmons NL. Functional organization of the bovine rumen epithelium. Am J Physiol Regul Integr Comp Physiol 288: R173-R181, 2005.

33. Hall MB, Huntington GB. Nutrient synchrony: sound in theory, elusive in practice. J Anim Sci 86: E287-E292, 2008.

34. Harmeyer J, Birk R, Varady J, Martens H. Kinetics of urea metabolism in protein-free fed sheep. Zeitschr Tierphysiol Tierernähr Futtermittelkd 31: $239-248,1973$.

35. Harmeyer J, Martens H. Aspects of urea metabolism in ruminants with reference to the goat. J Dairy Sci 63: 1707-1728, 1980.

36. Harmeyer J, Varady J, Birk R. Kinetics of urea metabolism in small ruminants during feeding and hunger. Arch Tierernahr 23: 461-481, 1973

37. Hoch DH, Finkelstein A. Gating of large toxin channels by pH. Ann NY Acad Sci 456: 33-35, 1985.

38. Houpt TR, Houpt KA. Transfer of urea nitrogen across the rumen wall. Am J Physiol 214: 1296-1303, 1968.

39. Inoue H, Jackson SD, Vikulina T, Klein JD, Tomita K, Bagnasco SM. Identification and characterization of a Kidd antigen/UT-B urea transporter expressed in human colon. Am J Physiol Cell Physiol 287: C30C35, 2004.

40. Isozaki T, Lea JP, Tumlin JA, Sands JM. Sodium-dependent net urea transport in rat initial inner medullary collecting ducts. J Clin Invest 94 1513-1517, 1994.

41. Kennedy P, Milligan L. The degradation and utilization of endogenous urea in the gastrointestinal tract of ruminants: a review. Can J Anim Sci 60: 205-221, 1980.
42. Kersting U, Dantzler DW, Oberleithner H, Silbernagl S. Evidence for an acid $\mathrm{pH}$ in rat renal inner medulla: paired measurements with liquid ion-exchange microelectrodes on collecting ducts and vasa recta. Pflïgers Arch 426: 354-356, 1994.

43. Lang I, Martens H. Na transport in sheep rumen is modulated by voltage-dependent cation conductance in apical membrane. Am J Physiol Gastrointest Liver Physiol 277: G609-G618, 1999.

44. Lapierre H, Lobley G. Nitrogen recycling in the ruminant: a review. $J$ Dairy Sci 84: E223-E236, 2001.

45. Leonhard-Marek S, Breves G, Busche R. Effect of chloride on $\mathrm{pH}$ microclimate and electrogenic $\mathrm{Na}^{+}$absorption across the rumen epithelium of goat and sheep. Am J Physiol Gastrointest Liver Physiol 291: G246-G252, 2006.

46. Levitt DG, Mlekoday HJ. Reflection coefficient and permeability of urea and ethylene glycol in the human red cell membrane. J Gen Physiol 81: 239-253, 1983.

47. Li S, Sato S, Yang X, Preisig PA, Alpern RJ. Pyk2 activation is integral to acid stimulation of sodium/hydrogen exchanger 3. J Clin Invest 114: 1782-1789, 2004.

48. Ludden PA, Stohrer RM, Austin KJ, Atkinson RL, Belden EL, Harlow HJ. Effect of protein supplementation on expression and distribution of urea transporter-B in lambs fed low-quality forage. J Anim Sci 87: 1354-1365, 2009.

49. Ludden PA, Stohrer RM, Austin KJ, Atkinson RL, Belden EL, Harlow HJ. Effect of protein supplementation on expression and distribution of urea transporter-B in lambs fed low-quality forage. J Anim Sci 87: $1354-1365,2009$.

50. Marini J, Sands J, Van Amburgh M. Urea transporters and urea recycling in ruminants. In: Ruminant Physiology, edited by Sejrsen K, Hvelplund T, Nielsen M. Wageningen, The Netherlands: Wageningen Academic, 2006, p. 155-171.

51. Marini JC, Klein JD, Sands JM, Van Amburgh ME. Effect of nitrogen intake on nitrogen recycling and urea transporter abundance in lambs. $J$ Anim Sci 82: 1157-1164, 2004.

52. Marini JC, Van Amburgh ME. Nitrogen metabolism and recycling in Holstein heifers. J Anim Sci 81: 545-552, 2003.

53. Martens H, Gäbel G. Transport of $\mathrm{Na}$ and $\mathrm{Cl}$ across the epithelium of ruminant forestomachs: rumen and omasum. A review. Comp Biochem Physiol A Comp Physiol 90: 569-575, 1988.

54. Martens H, Gäbel G, Strozyk B. Mechanism of electrically silent Na and $\mathrm{Cl}$ transport across the rumen epithelium of sheep. Exp Physiol 76: 103-114, 1991.

55. Maser P, Grether-Buhler Y, Kaminsky R, Brun R. An anti-contamination cocktail for the in vitro isolation and cultivation of parasitic protozoa. Parasitol Res 88: 172-174, 2002.

56. Moe OW. Acute regulation of proximal tubule apical membrane $\mathrm{Na} / \mathrm{H}$ exchanger NHE-3: role of phosphorylation, protein trafficking, and regulatory factors. J Am Soc Nephrol 10: 2412-2425, 1999.

57. Niemeyer MI, Cid LP, Yusef YR, Briones R, Sepulveda FV. Voltagedependent and -independent titration of specific residues accounts for complex gating of a $\mathrm{ClC}$ chloride channel by extracellular protons. $J$ Physiol 587: 1387-1400, 2009.

58. Norton BW, Janes AN, Armstrong DG. The effects of intraruminal infusions of sodium bicarbonate, ammonium chloride and sodium butyrate on urea metabolism in sheep. Br J Nutr 48: 265-274, 1982.

59. Norton BW, Mackintosh JB, Armstrong DG. Urea synthesis and degradation in sheep given pelleted-grass diets containing flaked barley. Br J Nutr 48: 249-264, 1982.

60. Obara Y, Dellow D, Nolan J. Effects of energy-rich supplements on nitrogen kinetics in ruminants. In: Physiological Aspects of Digestion and Metabolism in Ruminants, edited by Tsuda T, Sasaki Y, Kawashima R. San Diego, CA: Academic, 1991, p. 551-539.

61. Peters D. Molecular Adaptation of the Urea Transporter (UT) in Ruminal and Colonic Epithelia of Goats as Affected by Dietary Nitrogen and Energy Intake (PhD dissertation). Hannover, Germany: School of Veterinary Medicine Hannover, 2007.

62. Read B. Chemical constituents of camel's urine. J Biol Chem 4: 615-617, 1925.

63. Remond D, Bernard L, Chauveau B, Noziere P, Poncet C. Digestion and nutrient net fluxes across the rumen, and the mesenteric- and portaldrained viscera in sheep fed with fresh forage twice daily: net balance and dynamic aspects. Br J Nutr 89: 649-666, 2003. 
64. Remond D, Bernard L, Savary-Auzeloux I, Noziere P. Partitioning of nutrient net fluxes across the portal-drained viscera in sheep fed twice daily: effect of dietary protein degradability. Br J Nutr: 1-12, 2009.

65. Remond D, Chaise JP, Delval E, Poncet C. Net transfer of urea and ammonia across the ruminal wall of sheep. J Anim Sci 71: 2785-2792, 1993.

66. Remond D, Noziere P, Poncet C. Effect of time of starch supply to the rumen on the dynamics of urea and ammonia net flux across the rumen wall of sheep. Anim Res 51: 3-13, 2002.

67. Reynolds CK, Kristensen NB. Nitrogen recycling through the gut and the nitrogen economy of ruminants: an asynchronous symbiosis. J Anim Sci 86: E293-E305, 2008

68. Ritzhaupt A, Breves G, Schröder B, Winckler C, Shirazi-Beechey SP. Urea transport in gastrointestinal tract of ruminants: effect of dietary nitrogen (Abstract). Biochem Soc Trans 25: S490, 1997.

69. Ritzhaupt A, Wood I, Jackson A, Moran B, Shirazi-Beechey S. Isolation of a RT-PCR fragment from human colon and sheep rumen RNA with nucleotide sequence similarity to human and rat urea transporter isoforms (Abstract). Biochem Soc Trans 26: S122, 1998.

70. Sands JM. Mammalian urea transporters. Annu Rev Physiol 65: 543-566, 2003.

71. Sands JM. Urea transporter UT-B. UCSD-Nature Molecule Pages, 2006. doi:10.1038/mp.a002588.01.

72. Schmidt-Nielsen B, Osaki H. Renal response to changes in nitrogen metabolism in sheep. Am J Physiol 193: 657-661, 1958.

73. Schultheiss G, Martens H. Ca-sensitive Na transport in sheep omasum. Am J Physiol Gastrointest Liver Physiol 276: G1331-G1344, 1999.

74. Schweigel M, Freyer M, Leclercq S, Etschmann B, Lodemann U, Bottcher A, Martens H. Luminal hyperosmolarity decreases Na transport and impairs barrier function of sheep rumen epithelium. J Comp Physiol [B] 175: 575-591, 2005.

75. Sehested J, Diernaes L, Moller PD, Skadhauge E. Ruminal transport and metabolism of short-chain fatty acids (SCFA) in vitro: effect of SCFA chain length and pH. Comp Biochem Physiol A Mol Integr Physiol 123: 359-368, 1999.

76. Sehested J, Diernaes L, Moller PD, Skadhauge E. Transport of butyrate across the isolated bovine rumen epithelium-interaction with sodium, chloride and bicarbonate. Comp Biochem Physiol A Mol Integr Physiol 123: 399-408, 1999.

77. Sehested J, Diernaes L, Moller PD, Skadhauge E. Transport of sodium across the isolated bovine rumen epithelium: interaction with short-chain fatty acids, chloride and bicarbonate. Exp Physiol 81: 79-94, 1996.

78. Sellin JH. SCFAs: the enigma of weak electrolyte transport in the colon. News Physiol Sci 14: 58-64, 1999.

79. Simmonet H, Le Bars H, Molle J. Le cycle de l'urée administrée par voie buccale chez les ruminants. Séance Acad Sci 244: 943-945, 1957.

80. Simmons NL, Chaudhry AS, Graham C, Scriven ES, Thistlethwaite A, Smith CP, Stewart GS. Dietary regulation of ruminal bovine UT-B urea transporter expression and localization. J Anim Sci 87: 3288-3299, 2009.

81. Smith CP. Mammalian urea transporters. Exp Physiol 94: 180-185, 2009.

82. Smith CP, Rousselet G. Facilitative urea transporters. J Membr Biol 183: 1-14, 2001.

83. Stewart GS, Graham C, Cattell S, Smith TP, Simmons NL, Smith CP. UT-B is expressed in bovine rumen: potential role in ruminal urea transport. Am J Physiol Regul Integr Comp Physiol 289: R605-R612, 2005

84. Stumpff F, Bondzio A, Einspanier R, Martens H. Effects of the Bacillus thuringiensis toxin Cry1 Ab on membrane currents of isolated cells of the ruminal epithelium. J Membr Biol 219: 37-47, 2007.

85. Stumpff F, Martens H, Bilk S, Aschenbach JR, Gäbel G. Cultured ruminal epithelial cells express a large-conductance channel permeable to chloride, bicarbonate, and acetate. Pflügers Arch 457: 1003-1022, 2009.

86. Theurer CB, Huntington GB, Huber JT, Swingle RS, Moore JA. Net absorption and utilization of nitrogenous compounds across ruminal, intestinal, and hepatic tissues of growing beef steers fed dry-rolled or steam-flaked sorghum grain. J Anim Sci 80: 525-532, 2002.

87. Thorlacius SO, Dobson A, Sellers AF. Effect of carbon dioxide on urea diffusion through bovine ruminal epithelium. Am J Physiol 220: 162-170, 1971

88. Tripathi S, Morgunov N, Boulpaep EL. Submicron tip breakage and silanization control improve ion-selective microelectrodes. Am J Physiol Cell Physiol 249: C514-C521, 1985.

89. Von Engelhardt W, Nickel W. Die Permeabilität der Pansenwand für Harnstoff, Antipyrin und Wasser. Pflügers Arch 286: 57-75, 1965.

90. Von Engelhardt W, Nickel W. Factors influencing the endogenous urea-N secretion and utilization in the gastrointestinal tract. In: Ruminants Digestion and Feed Evaluation, edited by Osboum D, Beever D, Thomson D. London: Agricultural Research Council, 1978, p. 4.1-4.12.

91. Wakabayashi S, Hisamitsu T, Pang T, Shigekawa M. Kinetic dissection of two distinct proton binding sites in $\mathrm{Na}^{+} / \mathrm{H}^{+}$exchangers by measurement of reverse mode reaction. J Biol Chem 278: 43580-43585, 2003.

92. Walter A, Gutknecht J. Permeability of small nonelectrolytes through lipid bilayer membranes. J Membr Biol 90: 207-217, 1986.

93. Walter A, Hastings D, Gutknecht J. Weak acid permeability through lipid bilayer membranes. Role of chemical reactions in the unstirred layer. J Gen Physiol 79: 917-933, 1982.

94. Wolffram S, Frischknecht R, Scharrer E. Influence of theophylline on the electrical potential difference and ion fluxes $(\mathrm{Na}, \mathrm{Cl}, \mathrm{K})$ across the isolated rumen epithelium of sheep. Zentralbl Veterinarmed A 36: 755762, 1989

95. Yang B, Bankir L. Urea and urine concentrating ability: new insights from studies in mice. Am J Physiol Renal Physiol 288: F881-F896, 2005. 